Article

\title{
The Impact of Uncertainties in African Biomass Burning Emission Estimates on Modeling Global Air Quality, Long Range Transport and Tropospheric Chemical Lifetimes
}

\author{
Jason E. Williams ${ }^{1}{ }^{*}$, Michiel van Weele ${ }^{1}$, Peter F. J. van Velthoven ${ }^{1}$, Marinus P. Scheele ${ }^{1}$, \\ Catherine Liousse ${ }^{2}$ and Guido R. van der Werf ${ }^{3}$
}

1 Chemistry and Climate Division, Royal Netherlands Institute (KNMI), P.O. Box 201,

De Bilt 3730 AE, The Netherlands; E-Mails: weelemv@knmi.nl (M.W.);

velthove@knmi.nl (P.F.J.V.); scheele@knmi.nl (M.P.S.)

2 Laboratoire d'Aerologie, UMR 5560, 31400 Toulouse, France;

E-Mail: Catherine.Liousse@aero.obs-mip.fr

3 Department of Hydrology and Geo-Environmental Sciences, Faculty of Earth and Life Sciences, Vrije Universiteit, Amsterdam 1081 HV, The Netherlands; E-Mail: guido.van.der.werf@falw.vu.nl

* Author to whom correspondence should be addressed; E-Mail: williams@knmi.nl;

Tel.: +31-302-206-748; Fax: +31-302-210-407.

Received: 25 December 2011; in revised form: 19 January 2012 / Accepted: 19 January 2012 /

Published: 9 February 2012

\begin{abstract}
The chemical composition of the troposphere in the tropics and Southern Hemisphere $(\mathrm{SH})$ is significantly influenced by gaseous emissions released from African biomass burning (BB). Here we investigate how various emission estimates given in bottom-up BB inventories (GFEDv2, GFEDv3, AMMABB) affect simulations of global tropospheric composition using the TM4 chemistry transport model. The application of various model parameterizations for introducing such emissions is also investigated. There are perturbations in near-surface ozone $\left(\mathrm{O}_{3}\right)$ and carbon monoxide $(\mathrm{CO})$ of $\sim 60-90 \%$ in the tropics and $\sim 5-10 \%$ in the $\mathrm{SH}$ between different inventories. Increasing the update frequency of the temporal distribution to eight days generally results in decreases of between $\sim 5$ and $10 \%$ in near-surface mixing ratios throughout the tropics, which is larger than the influence of increasing the injection heights at which $\mathrm{BB}$ emissions are introduced. There are also associated differences in the long range transport of pollutants throughout the $\mathrm{SH}$, where the composition of the free troposphere in the $\mathrm{SH}$ is sensitive to the chosen BB inventory. Analysis of the chemical budget terms reveals that the influence of increasing the tropospheric $\mathrm{CO}$ burden due to $\mathrm{BB}$ on oxidative capacity of the
\end{abstract}


troposphere is mitigated by the associated increase in $\mathrm{NO}_{\mathrm{x}}$ emissions (and thus $\mathrm{O}_{3}$ ) with the variations in the $\mathrm{CO} / \mathrm{N}$ ratio between inventories being low. For all inventories there is a decrease in the tropospheric chemical lifetime of methane of between 0.4 and $0.8 \%$ regardless of the $\mathrm{CO}$ emitted from African $\mathrm{BB}$. This has implications for assessing the effect of inter-annual variability in BB on the annual growth rate of methane.

Keywords: African biomass burning; emission inventories; long range transport; air quality; methane lifetimes

\section{Introduction}

The release of large quantities of trace gas pollutants into the tropical troposphere from human burning practices and wildfires in Africa exerts a significant influence on global atmospheric composition, most importantly on the relatively pristine Southern Hemisphere (SH), tropical Atlantic [1-3] and around the burning regions. The resulting emissions from biomass burning (BB) impact directly on air quality by reducing visibility with concurrent enhancement in aerosol concentrations and associated reduction in photochemical activity. It has also been shown that the long range transport of pollutants emitted from BB can affect air quality thousands of kilometers away from the source [4]. It is estimated that open burning in Africa accounts for more than $50 \%$ of the total global BB emissions during any typical year [5,6]. It is therefore important to quantify the sensitivity of SH atmospheric composition to the uncertainty associated with African BB emission estimates.

The large interannual variability in the timing, distribution and extent of burning events can presently be mapped by making use of satellite observations and using the total burned area products [6-9]. To quantify the strength of the emission sources methodologies have been developed which combine such satellite observations with, e.g., terrestrial ecosystem models that account for differences in both land type and the availability of biomass for burning. This has lead to the development of a number of bottom-up emission inventories for use in three-dimensional global chemistry-transport models (3D global CTMs) [6,8,9]. A recent intercomparison of BB emission inventories for the year 2003 has highlighted large differences in both the seasonality and the total flux of gases emitted from tropical burning regions [10]. This study concluded that no preference can be given towards which methodology captures BB events most accurately, where there are both seasonal and regional differences in the performance of each inventory. This introduces significant uncertainty in the associated emissions of $\mathrm{CO}$, nitrogen oxides $\left(\mathrm{NO}_{\mathrm{x}}\right)$, non-methane hydrocarbons (NMHCs) and carbonaceous aerosols from BB emission sources. Thus, the most advanced bottom-up BB inventories that are currently available for use in 3D global CTMs exhibit significant differences in the integrated seasonal fluxes.

The strong convective uplift of BB emissions due to the increased air buoyancy above fires means that $\mathrm{BB}$ emissions exhibit a vertical injection profile that is commonly accounted for in $3 \mathrm{D}$ global CTMs [11]. The vertical distribution can be constrained using statistical composites derived using satellite measurements [12], with injection heights being dependant on the cumulative effects of fire intensity, land type, season and the local meteorological parameters. Although BB emissions in the 
tropics are rarely injected directly into the free troposphere (FT) [13,14], the long range transport out of the main burning regions can be influenced by the method with which BB emissions are introduced into large-scale atmospheric models [3]. Therefore, the description of BB emissions in global CTMs may have consequences concerning the fraction of the emitted species transported away from the source regions and the subsequent conclusions drawn as to the importance of African $\mathrm{BB}$ for the chemical composition of the troposphere in the tropics and $\mathrm{SH}$.

Typical applications of 3D global CTMs include: (i) the quantification of the long range transport of pollutants between continents and more remote locations; (ii) the investigation of chemical source-receptor relationships; and (iii) the provision of estimates of the atmospheric lifetimes of key trace gases such as $\mathrm{CO}(\tau \mathrm{CO}), \mathrm{O}_{3}\left(\tau \mathrm{O}_{3}\right)$ and $\mathrm{CH}_{4}(\tau \mathrm{CH} 4)$. Recent multi-model intercomparison studies estimate that in large-scale global models $\tau \mathrm{CO}, \tau \mathrm{O} 3$ and $\tau \mathrm{CH} 4$ have typical values of $\sim 2$ months, $\sim 22$ days and $\sim 8.7$ years, respectively $[15,16]$. These chemical lifetimes control the impact of emission sources on air quality far away from the source area by changing the resident surface concentrations [17]. Moreover, any increases in the global burdens of the greenhouse gases $\mathrm{CH}_{4}$ and $\mathrm{O}_{3}$ impact on climate due to their warming potential. Such warming has the potential to induce a positive feedback on wildfire incidence via more frequent drought conditions [18].

The removal of $\mathrm{CO}$ and $\mathrm{CH}_{4}$ is principally governed by the resident concentration of the $\mathrm{OH}$ radical formed via the photolysis of $\mathrm{O}_{3}$ in the presence of $\mathrm{H}_{2} \mathrm{O}$, where $\mathrm{O}_{3}$ is efficiently regenerated in the presence of $\mathrm{NO}_{\mathrm{x}}$ and sunlight. A chemical budget analysis from a typical CTM simulation reveals that $\mathrm{CO}$ and $\mathrm{CH}_{4}$ scavenge $\sim 40 \%$ and $\sim 16 \%$ of the available global $\mathrm{OH}$ in the troposphere, respectively, with a large fraction of the oxidation occurring in the tropics $\left(30^{\circ} \mathrm{S}-30^{\circ} \mathrm{N}\right)$. The impacts of $\mathrm{BB}$ emissions on $\tau_{\mathrm{CH} 4}$ are manifold, with the net impact being rather uncertain. For instance, in response to the widespread 1997 Indonesian wildfires, Duncan et al. [19] have shown that $\tau_{\mathrm{CH} 4}$ increases due to large-scale reductions in $\mathrm{OH}(>20 \%)$. This reduction was ascribed to enhanced $\mathrm{CO}$ emissions released from the fires, enhanced heterogeneous loss of $\mathrm{HO}_{\mathrm{x}}$ radicals and reductions in UV light caused by increases in BB aerosols. However other more recent studies have suggested that the observed increase in $\mathrm{CH}_{4}$ during 1997 measured by the NOAA Earth System Research Laboratory (ESRL) surface monitoring network was due to enhanced $\mathrm{CH}_{4}$ emissions directly from increased $\mathrm{BB}$ rather than due to increased competition for $\mathrm{OH}$ [20]. Other studies suggest a combination of both $\mathrm{CH}_{4}$ emissions and lifetime changes to explain the variable annual growth rate [21]. Also the anomalous climatic conditions that favour intensive $\mathrm{BB}$ events result in a dry, arid environment with reduced cloudiness, which impact $\mathrm{OH}, \mathrm{O}_{3}$ (via lower biogenic and $\mathrm{BB} \mathrm{NO} \mathrm{N}_{x}$ ), $\tau \mathrm{CO}$ and $\tau \mathrm{CH}_{4}$.

For anthropogenic emissions it has been shown that the global $\mathrm{OH}$ distribution, and thus $\tau \mathrm{CH}_{4}$, is significantly affected by the ratio of $\mathrm{CO}$ and $\mathrm{N}$ (as nitrogen oxides) emitted into the atmosphere [22,23]. For $\mathrm{BB}$ the $\mathrm{CO} / \mathrm{N}$ ratio is typically much higher than anthropogenic emissions due to incomplete combustion processes [23]. This has the potential to impact the global $\mathrm{CO}$ burden, and thus $\tau \mathrm{CH}_{4}$, due to a lower fraction of the emitted $\mathrm{CO}$ being oxidized in/around the source region. To date to our knowledge there has been no similar investigation as to how the potential variability in the $\mathrm{CO} / \mathrm{N}$ ratio from $\mathrm{BB}$ emission inventories impacts on the atmospheric lifetimes of abundant trace gases when applied in a global CTM, which is a major focus of this study.

In this paper we investigate the uncertainties introduced towards simulating global tropospheric composition associated with differences between bottom-up BB emission estimates when applied in a 
global 3D CTM. For this purpose we examine the influence on global air quality, the long range transport of pollutants out of BB source regions and the perturbations introduced in estimating global atmospheric lifetimes of dominant trace species. We also investigate the impact of increasing the update frequency with respect to the temporal distribution of $\mathrm{BB}$ emissions and the parameterization used for introducing tropical $\mathrm{BB}$ emission into the boundary layer on both tropical and $\mathrm{SH}$ composition. Finally we show that there is a compensating effect towards the perturbations introduced towards the oxidative capacity of the troposphere due to the $\mathrm{CO} / \mathrm{N}$ ratio defined in different $\mathrm{BB}$ emission inventories, which constrains the effects on the global lifetimes for dominant trace gases.

\section{Model Simulations and Emissions}

The global 3D CTM used for this study is TM4, where the version applied here has been comprehensively described elsewhere [3]. The model is run at a horizontal resolution of $3^{\circ} \times 2^{\circ}$ using 34 vertical levels with a model top of $0.1 \mathrm{hPa}$ and is driven by meteorological fields from the European Centre for Medium-Range Weather Forecasting (ECMWF) operational analysis. The model uses the modified CBM4 chemical mechanism [24] updated to include recent recommendations to the reaction rate data [25]. Photolysis rates are calculated using the parameterization of Landgraf and Crutzen [26], modified to account for attenuation effects by clouds and ground albedo [27]. The chosen simulation year is 2006, for which the distribution of both $\mathrm{CO}$ and $\mathrm{O}_{3}$ in TM4 have recently been evaluated against a host of different measurements taken in and around the African continent [3,28,29] and where burning intensity in Africa is representative of a typical year [6]. For global anthropogenic and biogenic emissions we use the emission inventories provided by the EU-RETRO project for the year 2000 (http://retro.enes.org).

In this study we principally focus on differences between $\mathrm{BB}$ inventories provided for the African domain (here defined as the region $34^{\circ} \mathrm{S}-34^{\circ} \mathrm{N}, 20^{\circ} \mathrm{W}-40^{\circ} \mathrm{E}$ ). $\mathrm{BB}$ emission estimates are taken from bottom-up BB inventories, namely: GFEDv2 [8], GFEDv3 [6], and AMMABB [9], for which large differences have been shown to exist in the emission estimates for both trace gases and aerosols $[9,10]$. For regions outside the African domain we adopt the GFEDv2 emission inventory for BB in all simulations. The update frequency of these inventories is monthly, where the original inventories are provided on either a $1^{\circ} \times 1^{\circ}$ or $0.5^{\circ} \times 0.5^{\circ}$ grid resolution and subsequently coarsened for application in TM4. To account for typical burning practises a daily burning cycle is applied to all $\mathrm{BB}$ emissions over the latitudinal range $20^{\circ} \mathrm{S}-20^{\circ} \mathrm{N}$ peaking at $2 \mathrm{pm}$ local time [30]. For the majority of simulations BB emissions between $20^{\circ} \mathrm{S}-20^{\circ} \mathrm{N}$ are introduced into the first $2 \mathrm{~km}$ of the troposphere, with $\sim 50 \%$ being placed between 0 and $1 \mathrm{~km}$ and $\sim 50 \%$ being placed between 1 and $2 \mathrm{~km}$. For the mid- and high latitudes, burning heights are adopted from the literature [11]. To quantify the global impact of African $\mathrm{BB}$ emissions on both long range transport and the atmospheric burdens and lifetimes of dominant trace species we perform a simulation where African BB emissions are turned off (referred to as NONE). In all simulations the $\mathrm{CH}_{4}$ surface concentrations are constrained by relaxation towards observations made at pristine locations as part of the NOAA surface network. This allows TM4 to capture the latitudinal gradient and seasonal cycles which are present, as well as the variability in the $\mathrm{CH}_{4}$ growth rate over recent decades [20]. Therefore differences in the estimates of direct $\mathrm{CH}_{4}$ emissions from $\mathrm{BB}$ are not accounted for in this study, although these are rather small typically 
ranging between 17 and $20 \mathrm{Tg} \mathrm{CH}_{4} \mathrm{yr}^{-1}$ [6,8]. In these simulations a $\mathrm{CH}_{4}$ surface gradient exists of $\sim 1,770 \mathrm{ppb}$ at $35^{\circ} \mathrm{S}$ and $\sim 1,850 \mathrm{ppb}$ at $35^{\circ} \mathrm{N}$. A one year spin-up period is adopted for all simulations using the relevant $\mathrm{BB}$ emission inventory available for the year 2005 .

Table 1. A definition of the sensitivity simulations conducted in this study. These different emission inventories are applied for the African domain only. All other regions use GFEDv2 monthly estimates with latitudinally dependant injection heights from Dentener et al. [11].

\begin{tabular}{cccc}
\hline $\begin{array}{c}\text { Definition of } \\
\text { Simulation }\end{array}$ & $\begin{array}{c}\text { Biomass Burning } \\
\text { Emission Inventory }\end{array}$ & $\begin{array}{c}\text { Injection } \\
\text { Height (km) }\end{array}$ & $\begin{array}{c}\text { Temporal Update } \\
\text { Frequency }\end{array}$ \\
\hline GFEDv2 & GFEDv2 & $0-2$ & Monthly \\
GFEDv3 & GFEDv3 & $0-2$ & Monthly \\
AMMABB & AMMABB & $0-2$ & Monthly \\
AMMABB_LOWNOX & AMMABB & $0-2$ & Monthly \\
8DAY & GFEDv2 & $0-2$ & 8 -day \\
HIGH-IH & GFEDv2 & $0-3$ & Monthly \\
\hline
\end{tabular}

Sensitivity studies are also defined to investigate the effect of increasing the update frequency of the temporal distribution of $\mathrm{BB}$ events and increasing the injection heights used for introducing tropical BB emissions (referred to as 8-DAY and HIGH-IH, respectively). For the 8-DAY simulation we adopted the GFEDv2 8-day emission inventory [6] where a new temporal distribution and emission flux is defined every 8 days of simulation time. For HIGH-IH we change the vertical distribution between $30^{\circ} \mathrm{S}$ and $30^{\circ} \mathrm{N}$ from the default (see above) to that derived from a 5-year record of satellite observations [12] which results in no emissions in the first $100 \mathrm{~m}, \sim 25 \%$ between 100 and 1,000 m, $\sim 50 \%$ between 1 and $2 \mathrm{~km}$ and $\sim 25 \%$ between 2 and $3 \mathrm{~km}$. Finally, to investigate the effect that BB $\mathrm{NO}_{\mathrm{x}}$ emissions have on mitigating the long range transport of $\mathrm{CO}$ we perform a simulation using the AMMABB inventory where the $\mathrm{BB} \mathrm{NO}_{\mathrm{x}}$ is reduced by 50\% (AMMABB_LOWNOX). An overview of all the simulations used for this study and the $\mathrm{BB}$ inventories adopted for Africa in each simulation are given in Table 1.

\section{Comparison of Biomass Burning Emission Inventories}

The three BB emission inventories analyzed here use a similar modeling approach for the derivation of emission estimates [10], where differences exist primarily due to the burned area product which is utilized and the input data (e.g., the definition and distribution of land types) to the modeling process. All BB emission inventories used in this study are commonly known as bottom-up inventories.

For the GFED inventories daily burnt area maps are derived from the Moderate Resolution Imaging Spectrophotometer (MODIS) [31,32]. The differences between versions 2 and 3 of the inventory are derived from changes that have been made to the method for calculating the monthly burned area product and fire activity from MODIS and the parameterizations applied in the Carnegie-AmesStanford-Approach (CASA) biogeochemical model [33] used for calculating plant productivity, tree mortality, leaf litterfall and combustion completeness. For the global burned area product this results in a $\sim 10 \%$ difference between versions used for deriving the GFEDv2 and GFEDv3 inventories [32], with a $\sim 60 \%$ increase for southern Africa. In total 13 different vegetation classes are defined ranging 
from deciduous needleleaf to Savanna, including both an Urban and Barren classification. A fixed vegetation map including fractional tree cover for the year 2001 is adopted regardless of the year [34]. The soil moisture component is calculated using precipitation values from the Global Precipitation Climatology Project (GPCP, [35]) and the temperature taken from climatological values. The CASA model produces a monthly input file for the derivation of $\mathrm{BB}$ emission fluxes on a $0.5^{\circ} \times 0.5^{\circ}$ grid resolution. The emission factors used for each of the seven different fire types are given in van der Werf et al. [6] and are based on the recommendations of Andreae and Merlet [36], except for peat fires which are based on Christian et al. [37]. That the GFEDv3 emission inventory is more recent means that it supersedes the GFEDv2 emission inventory, and subsequently reduces the uncertainty associated with emissions due to BB. In spite of the increase in the burned area the annual emission fluxes in the GFEDv3 inventory are generally lower for many regions when compared to the corresponding GFEDv2 inventory [6]. This leads to an associated decrease in the global CO emission flux for the GFEDv3 inventory, which has recently been questioned when comparing CO inversions performed using the 4DVAR version of TM5, optimized using surface measurements of CO [38] and CO inversions performed using the MOZART model using satellite observations from the MOPITT (Measurements of Pollution in the Troposphere) satellite instrument [39]. Details related to the uncertainties of the input parameters used for determining the GFEDv2 and GFEDv3 emission inventories are given in the literature [6,8].

Although two generations of the GFED inventory are applied in this study, no direct comparisons of CTM simulations using both versions of the inventory for African BB have appeared in the literature to our knowledge, thus warranting some investigation of the effects considering that GFEDv2 has been widely used during previous CTM studies [3,28]. Moreover, the 8-day product was only available for the GFEDv2 inventory at the time of this study. For the NMHC the GFED inventory provides a

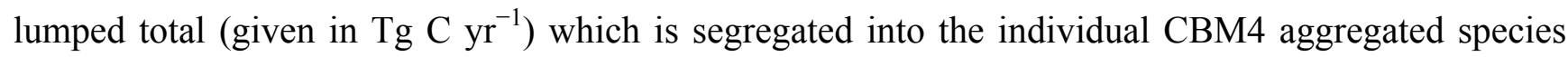
used for representing higher organics according to the ratios given in Table 2. Here the organic species in the modified CBM4 mechanism for which BB contribute are thus: PAR represents paraffinic bonds, ETH represents ethene $\left(\mathrm{CH}_{2}=\mathrm{CH}_{2}\right)$, OLE represents olefinic bonds, ALD2 represents aldehydes, MGLY represents methylgloxal $\left(\mathrm{CH}_{3} \mathrm{COCHO}\right)$ and $\mathrm{HCHO}$ represents formaldehyde.

Table 2. The ratios used for the segregation of the non-methane hydrocarbons (NMHC) emission fluxes provided by the GFED biomass burning emission inventory as an aggregated emission flux $(\mathrm{Tg} \mathrm{C})$ into transported trace species in the modified CBM4 chemical mechanism. For definitions of each species see the details provided in the text.

\begin{tabular}{cccc}
\hline $\begin{array}{c}\text { Modified CBM4 } \\
\text { Species }\end{array}$ & $\begin{array}{c}\text { Fraction of Total } \\
\text { Lumped NMHC }\end{array}$ & $\begin{array}{c}\text { Modified CBM4 } \\
\text { Species }\end{array}$ & $\begin{array}{c}\text { Fraction of Total } \\
\text { Lumped NMHC }\end{array}$ \\
\hline PAR & 0.286 & ALD2 & 0.022 \\
ETH & 0.125 & MGLY & 0.006 \\
OLE & 0.068 & HCHO & 0.005 \\
\hline
\end{tabular}

For the AMMABB inventory the L3JRC burned area product is used [40] derived using daily images from the VEGETATION sensor on the Satellite Pour 1' Observation de la Terre (SPOT) instrument, with corrections applied for the GLC3 (open deciduous broadleaved tree cover) and 
GLC12 (deciduous closed-open shrubs) ecosystems using intercomparisons of the LANDSAT and L3JRC products [9]. Also a fixed vegetation map for the year 2000 is adopted during the calculation of the emission fluxes [10]. The total emission estimate for each trace gas is calculated using the designated biomass density, burning efficiency and emission factors for 14 separate vegetation types [9]. The burning efficiency across vegetation types typical ranges from 0.25 (e.g., GLC1, broadleaf evergreen) to 0.9 (GLC11, Evergreen Shrubs). Again the emission factors used for the derivation of trace gas emissions are taken from Andreae and Merlet [36]. Each contribution is then weighted by the fraction of each vegetation type contained in the $0.5^{\circ} \times 0.5^{\circ}$ grid cell. The associated uncertainty related to each of the input parameters used to derive the emission fluxes are given in Liousse et al. [9].

For $\mathrm{NO}_{\mathrm{x}}$ emissions separate estimates are given for $\mathrm{NO}$ and $\mathrm{NO}_{2}$ to account for burning efficiency, although all $\mathrm{NO}_{\mathrm{x}}$ emissions are introduced as $\mathrm{NO}$ in TM4 for computational stability. For the NMHC a total of 49 different emission fluxes are provided for a diverse range of Volatile Organic Compounds (VOC's). These are partitioned into the CBM4 components following the recommendations given in Yarwood et al. [41].

Annual totals for the African $\mathrm{BB}$ emission estimates for $\mathrm{CO}, \mathrm{NO}_{\mathrm{x}}$ (as $\mathrm{N}$ ), and the $\mathrm{NMHC}$ (as $\mathrm{C}$ ) are given in Table 3, along with the associated $\mathrm{CO} / \mathrm{N}$ ratios. Also shown are the corresponding emission totals from anthropogenic and biogenic sources. The emissions from the AMMABB inventory are much higher than those provided in either GFEDv2 or GFEDv3 for all species, with differences of up to $\sim 65 \%$ in the annual totals for Africa as found in previous studies for other years [10]. Moreover, emissions due to $\mathrm{BB}$ dominate for the African continent regardless of the emission inventory which is employed showing the importance of African BB as a tropical emission source.

Table 3. The annual emission totals of reactive trace gases released from Africa $\left(34^{\circ} \mathrm{S}-34^{\circ} \mathrm{N}, 20^{\circ} \mathrm{W}-40^{\circ} \mathrm{E}\right)$ for 2006 as estimated by the various $\mathrm{BB}$ emission inventories adopted in this study. The numbers in parenthesis are the percentage contributions to the total annual global emissions emitted for each trace species. The corresponding $\mathrm{CO} / \mathrm{N}$ emission ratios for Africa are provided in the column on the far right.

\begin{tabular}{|c|c|c|c|c|}
\hline & $\begin{array}{c}\mathrm{CO} \\
\left(\mathrm{TgCO} \mathrm{yr}^{-1}\right)\end{array}$ & $\begin{array}{c}\mathrm{NO}_{\mathrm{x}} \\
\left(\mathrm{Tg} \mathrm{N} \mathrm{yr}^{-1}\right)\end{array}$ & $\begin{array}{c}\text { NMHC } \\
\left(\operatorname{Tg~C~yr~}^{-1}\right)\end{array}$ & CO/N Ratio \\
\hline GFEDv2 & $149.29(14.2)$ & $2.44(5.3)$ & $4.45(2.5)$ & 61.2 \\
\hline GFEDv3 & $143.82(13.8)$ & $2.10(4.5)$ & $4.45(2.5)$ & 68.5 \\
\hline AMMABB & $243.64(21.3)$ & $5.36(10.4)$ & $16.35(9.6)$ & 43.3 \\
\hline AMMBB_LOWNOX & $243.64(21.3)$ & $2.73(5.5)$ & $16.35(9.6)$ & 89.2 \\
\hline Anthropogenic & $66.70(6.4)$ & $3.85(7.9)$ & $7.78(12.5)$ & 17.8 \\
\hline Biogenic & $28.58(2.7)$ & $2.19(4.5)$ & $9.84(15.9)$ & 13.1 \\
\hline
\end{tabular}

Figure 1 shows differences in the seasonal cycle of Africa $\mathrm{BB}$ emissions for both $\mathrm{NO}_{\mathrm{x}}(\mathrm{left})$ and $\mathrm{CO}$ (middle), along with the corresponding seasonal cycle in the $\mathrm{CO} / \mathrm{N}$ ratios (right). The two seasonal peaks in BB emissions occur from November to January (NDJ) in the Northern Hemisphere (NH) and from June to September (JJAS) in the SH. Largest differences occur between GFEDv2 and AMMABB during boreal summertime and are associated with the intense burning which occurs in southern Africa during this season. For $\mathrm{NO}_{\mathrm{x}}$, differences of $\sim 50 \%$ also occur from $\mathrm{NH}$ burning during boreal 
wintertime. For both of the GFED inventories there are larger monthly emissions from NH burning than $\mathrm{SH}$ burning, whereas for $\mathrm{AMMABB}$ the emissions from $\mathrm{SH}$ burning dominate. Comparing GFEDv3 and AMMABB shows that the CO BB emission fluxes become quite similar from January to April compared to the corresponding $\mathrm{NO}_{\mathrm{x}}$ emissions. Given that the emission factors for each trace species are similar between inventories this difference is related to the cumulative effect of differences in the burned area product, vegetation classifications and land use maps. The seasonal variation in the $\mathrm{CO} / \mathrm{N}$ ratio shows that although the magnitude of the monthly $\mathrm{CO} / \mathrm{N}$ ratios differ by $\sim 30-50 \%$, the seasonal variation becomes more similar between the GFEDv3 and the AMMABB inventories, although for the AMMABB inventory there is a maxima during August.

Figure 1. Comparison of the monthly African $\left(34^{\circ} \mathrm{S}-36^{\circ} \mathrm{N}, 20^{\circ} \mathrm{W}-40^{\circ} \mathrm{E}\right)$ emission totals for (left) $\mathrm{NO}_{\mathrm{x}}$ and (middle) $\mathrm{CO}$ in $\mathrm{Tg} \mathrm{N} /$ month and $\mathrm{Tg} \mathrm{CO} /$ month, respectively. The seasonal variation in the corresponding $\mathrm{CO} / \mathrm{N}$ ratio is also shown (right). The inventories are: (-) GFEDv2, (‥) GFEDv3 and (--) AMMABB.
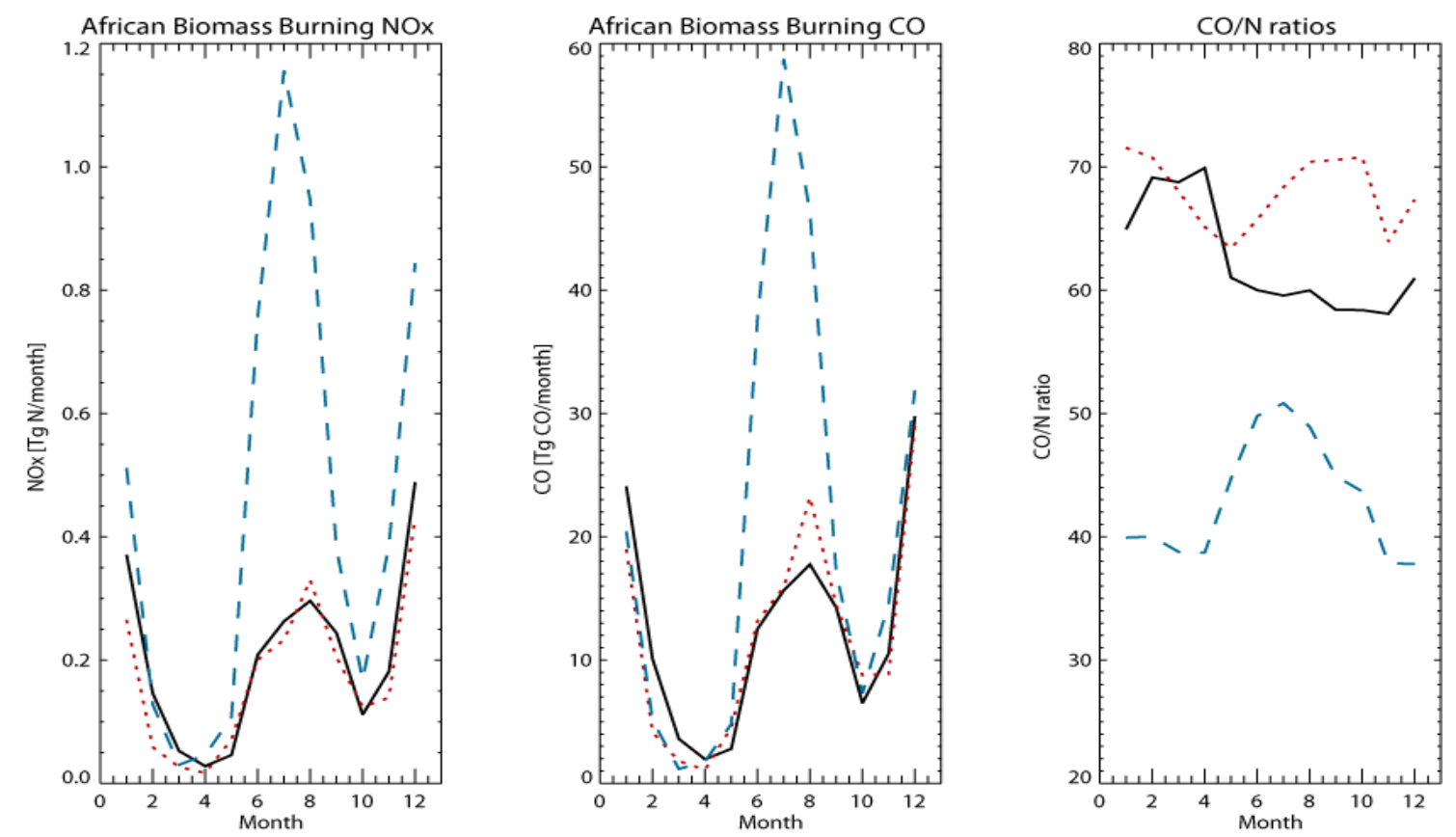

To highlight the differences in the temporal distribution of the emission estimates provided in each inventory, Figures 2 and 3 show the monthly BB emission estimates for CO from Africa for January, April, July and October 2006 as provided in the GFEDv3 and AMMABB emission inventories, respectively. The corresponding $\mathrm{CO} / \mathrm{N}$ ratios are also shown in all instances. Each emission inventory is shown on a $0.5^{\circ} \times 0.5^{\circ}$ resolution. Both figures also show that there is significant variability with respect to the intensity of fires across any given latitude range for any given month. Comparing the total burned area in Africa for 2006 gives $195 \times 10^{4} \mathrm{~km}^{2}$ for the L3JRC product [42] and $237 \times 10^{4} \mathrm{~km}^{2}$ for the GFEDv3 product [32]. This results in the burned area in the L3JRC product being approximately half as large in northern Africa and two-thirds as large in southern Africa [32]. Therefore, the amount of emissions released per unit area burnt is larger in the AMMABB inventory. 
Figure 2. The temporal distribution in African BB for (top to bottom) January, April, July and October during 2006 as provided in the GFEDv3 emission inventory. The corresponding $\mathrm{CO} / \mathrm{N}$ ratio is also provided for all months.
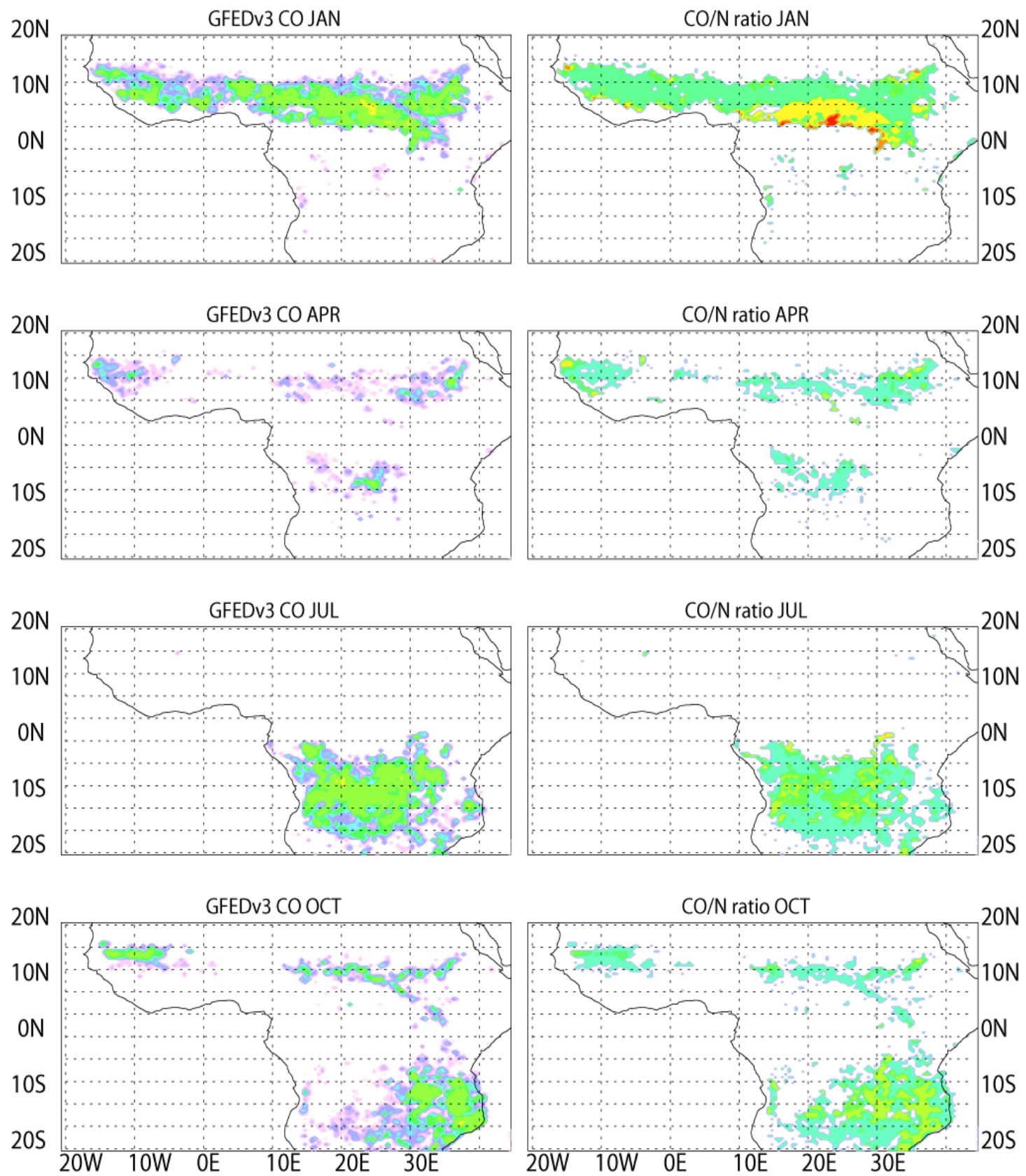

$100 \times \operatorname{Tg}$ CO month m-2

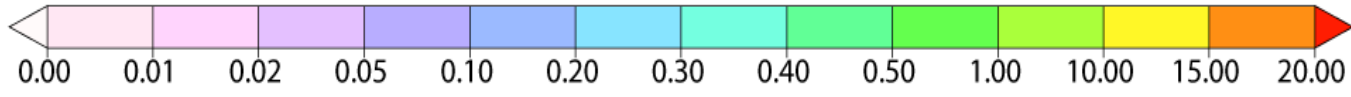

$\mathrm{CO} / \mathrm{N}$ ratio

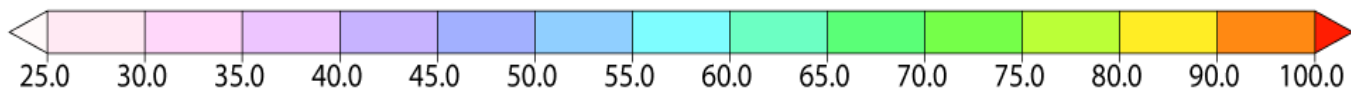


Figure 3. As for Figure 2 except showing the temporal distribution of the AMMABB emission inventory.
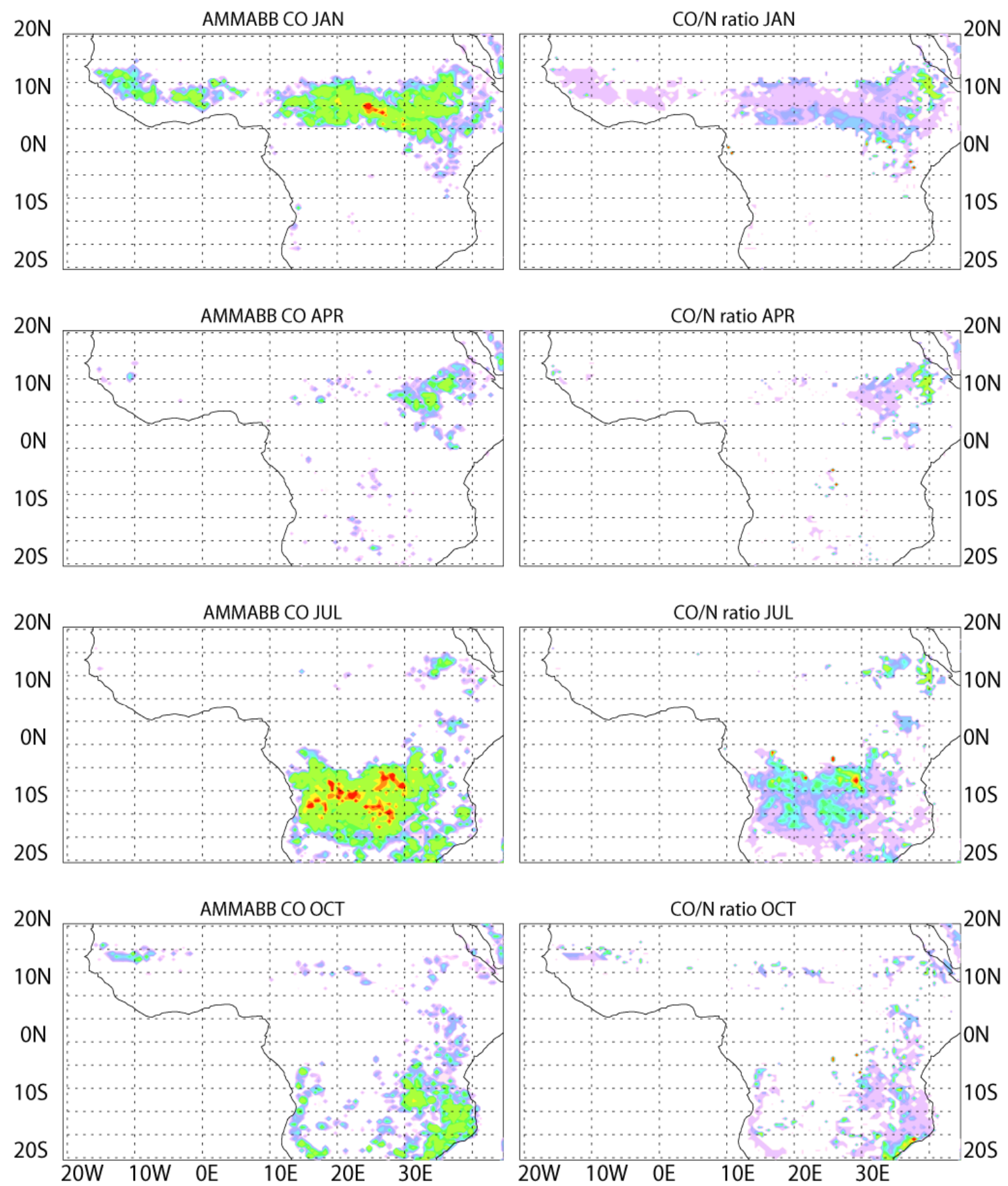

$100 \times \mathrm{Tg}$ CO month m-2

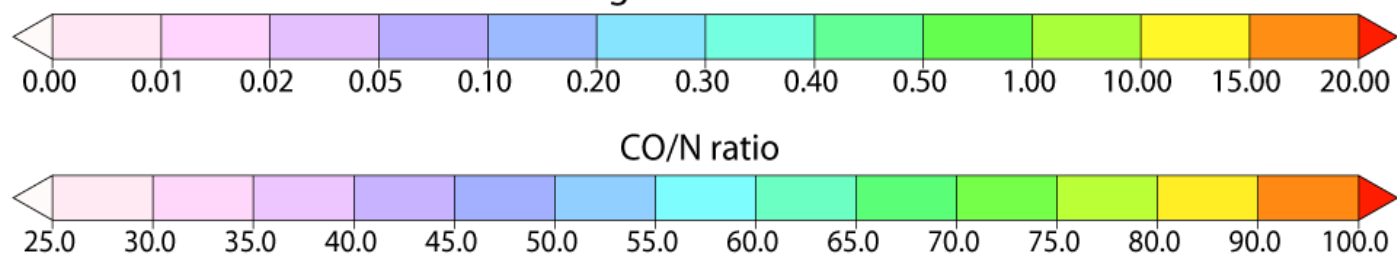

In general the seasonal hemispheric distribution is similar, although the extent of burning below (above) the equator is larger in the AMMABB inventory for January (July). The longitudinal distribution in the burning pattern is also very different, where the GFEDv3 inventory has more 
burning in West Africa throughout the year. Conversely the AMMABB inventory displays more burning activity towards the Horn of Africa. Previous studies have concluded that there is an underestimation in BB in Western Africa in the AMMABB inventory as a result of the L3JRC burned area product $[10,40]$. Stroppiana et al. [10] have performed direct comparisons of BB CO emissions derived for Africa during 2003 between the GFEDv3 and AMMABB inventories and found a correlation co-efficient $\left(R^{2}\right)$ of 0.47 , which agrees better than for other regions such as e.g., North America, where the reliability of the L3JRC burnt area product is thought to be low [42]. They have also shown that for the three main land cover types (forest, savanna/grassland and agriculture) there are significant differences in the contribution of $\mathrm{CO}$ from each land type in Africa.

For much of the burning region the GFEDv3 inventory has $\mathrm{CO} / \mathrm{N}$ ratios that range between 60 and 70 , although there are regions in southern Africa which ratios can be as high as 80 . The corresponding ratios in the $A M M A B B$ inventory are typically lower around 35 to 50 , although the more intense burning events have ratios which are higher around 70 to 90 . When applied in TM4, the spatial variability in these $\mathrm{CO} / \mathrm{N}$ ratios becomes somewhat homogenized due to the coarsening step onto the horizontal grid of $3^{\circ} \times 2^{\circ}$. Thus using a model with higher resolution would introduce more significant regional variability into the African domain with respect to the $\mathrm{CO} / \mathrm{N}$ ratio compared to the simulations presented here, which would subsequently affect tropospheric $\mathrm{O}_{3}$ production [43].

Finally we investigate the differences between the GFEDv2 and GFEDv2 8-day emission inventories for African $\left(34^{\circ} \mathrm{S}-34^{\circ} \mathrm{N}, 20^{\circ} \mathrm{W}-40^{\circ} \mathrm{E}\right) \mathrm{CO}$ emissions. Even if the annually integrated emission totals are approximately equal between the two different GFEDv2 inventories, the segregation of the emission fluxes into 8-day composites may result in different totals when the resulting emission is summed per calendar month. Figure 4 shows the percentage differences in the monthly BB emissions fluxes from the African domain for 2006, as given in the $1^{\circ} \times 1^{\circ}$ emission inventories used in this study. Also shown are the absolute differences in Tg CO and Gg N per month. It can be seen that there are generally decreases during the intensive BB seasons NDJ and JJAS. Integrating the absolute difference for the entire year results in a decrease of $0.5 \mathrm{Tg} \mathrm{CO} \mathrm{yr}^{-1}$ and $8.9 \mathrm{Gg} \mathrm{N} \mathrm{yr}^{-1}$ when applying the GFEDv2 8-day emission inventory for the African domain. These differences shift in location as governed by the location of the seasonal BB activity.

Figure 4. The percentage difference in the monthly BB emission fluxes from Africa $\left(34^{\circ} \mathrm{S}-34^{\circ} \mathrm{N}, 20^{\circ} \mathrm{W}-40^{\circ} \mathrm{E}\right)$ between the GFEDv2 and GFEDv2 8-day emission inventories. Also shown is the absolute difference in $\mathrm{Tg} \mathrm{CO}$ and $\mathrm{Gg} \mathrm{N}$ per month. The differences are calculated as (8-DAY-MONTHLY)/MONTHLY $\times 100$.
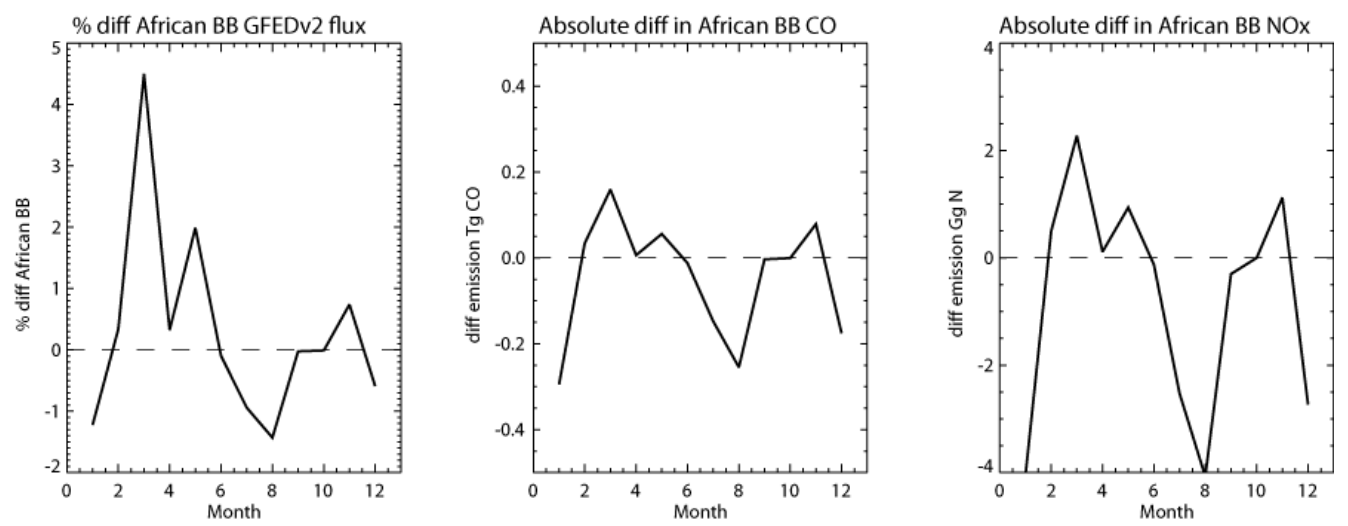


\section{The Impact on the Composition of the Southern Hemisphere}

\subsection{Surface Air Quality; Influence of BB Inventory}

Local air quality in the SH has been shown to be sensitive to African BB, with simulated effects occurring thousands of kilometers away in Central America towards the west and Oceania towards the east $[4,44]$. Here we investigate the sensitivity of near-surface air quality towards the uncertainty in the bottom-up BB emission estimates provided for 2006, where the different $\mathrm{CO} / \mathrm{N}$ ratios and flux estimates introduce variations in the chemical processing of polluted air-masses, and thus the long range transport of emissions out of Africa. Figure 5 shows the seasonal differences in $\mathrm{CO}, \mathrm{O}_{3}, \mathrm{NO}_{\mathrm{x}}$, and $\mathrm{OH}$ in the lowest few kilometers of the troposphere for December-January-February (DJF) and June-July-August (JJA) when comparing simulations using the GFEDv3 and AMMABB emission inventories. This represents the maximal differences between the chosen BB inventories listed in Table 3, and therefore will introduce the largest differences between simulations.

In general it can be seen that the variability introduced by the uncertainty associated with SH BB is significantly larger than the uncertainty associated with $\mathrm{NH} \mathrm{BB}$, where the magnitude of the differences in African BB emissions are largest for JJAS (see Figure 1). Interestingly there are also decreases in near-surface $\mathrm{CO}$ and $\mathrm{NO}_{\mathrm{x}}$ around the West African coast related to the differences in the distribution of the regional fire activity between the $\mathrm{BB}$ emission inventories. Previous comparisons between inventories have shown that the AMMABB inventory underestimates BB emissions from Western Africa compared to other BB emission inventories [10]. The seasonal differences in the burning activity introduce a strong signature in the impact on near-surface air quality in the SH. For DJF the effect in the $\mathrm{SH}$ is limited due to the southerly transport of BB plumes from burning events in northern Africa being limited to the westerly outflow regions as a result of the blocking which occurs due to the location of the Intertropical Convergence Zone (ITCZ). This is in contrast to JJA, where the most intense burning shifts towards the south enhancing the impact occur on $\mathrm{SH}$ air quality $(\sim 5-10 \%$ for $\mathrm{CO}$ ). For tropospheric $\mathrm{O}_{3}$ maximal impact occurs in and around the African continent as would be expected considering the differences in the atmospheric lifetimes between both trace species. The differences in the $\mathrm{SH}$ are principally caused by increases in the in situ chemical production, which occurs away from the African BB source regions. This is due to the corresponding increases in the long range transport of $\mathrm{NO}_{\mathrm{x}}$ as peroxy-acetyl nitrate (PAN) (not shown). Once PAN is lofted into the FT the low temperatures result in an atmospheric lifetime of tens of days, allowing transport out of the main source regions. Upon decomposition PAN acts as an important chemical reservoir for introducing reactive nitrogen into remote regions [45]. The associated impact on $\mathrm{OH}$ is limited to near the source regions, as governed by the increases in tropospheric $\mathrm{O}_{3}$.

When performing a similar comparison between the GFEDv2 and GFEDv3 simulations (not shown), the differences in the monthly emission fluxes between the two emission inventories shown in Figure 1 introduce a seasonal dependency in the absolute differences in the resident concentrations near the surface in and around Africa. There is some degree of temporal variability introduced between both emission inventories, which is somewhat dependant on the particular trace species. For instance, for DJF the GFEDv3 emission inventory estimates a higher emission flux for $\mathrm{CO}$ around Nigeria and a lower (higher) emission flux for $\mathrm{NO}_{\mathrm{x}}$ in the $\mathrm{NH}$ BB regions towards the east (north) of Africa. For 
the westerly outflow there are generally increases during DJF and decreases during JJA, where maximal differences are of the order of $\sim 10 \%$. For the background there are generally decreases (increases) in $\mathrm{CO}\left(\mathrm{O}_{3}\right)$ of a few percent. Thus, the main differences are limited to the tropics $\left(30^{\circ} \mathrm{S}-30^{\circ} \mathrm{N}\right)$.

Figure 5. The relative percentage differences in the global near-surface concentrations for (a) $\mathrm{CO}$; (b) $\mathrm{O}_{3}$; (c) $\mathrm{NO}_{\mathrm{x}}$ and (d) $\mathrm{OH}$ for seasons DJF (left) and JJA (right) between GFEDv3 and AMMABB. The relative differences are calculated as $(($ AMMABB-GFEDv3)/GFEDv3) $\times 100$.
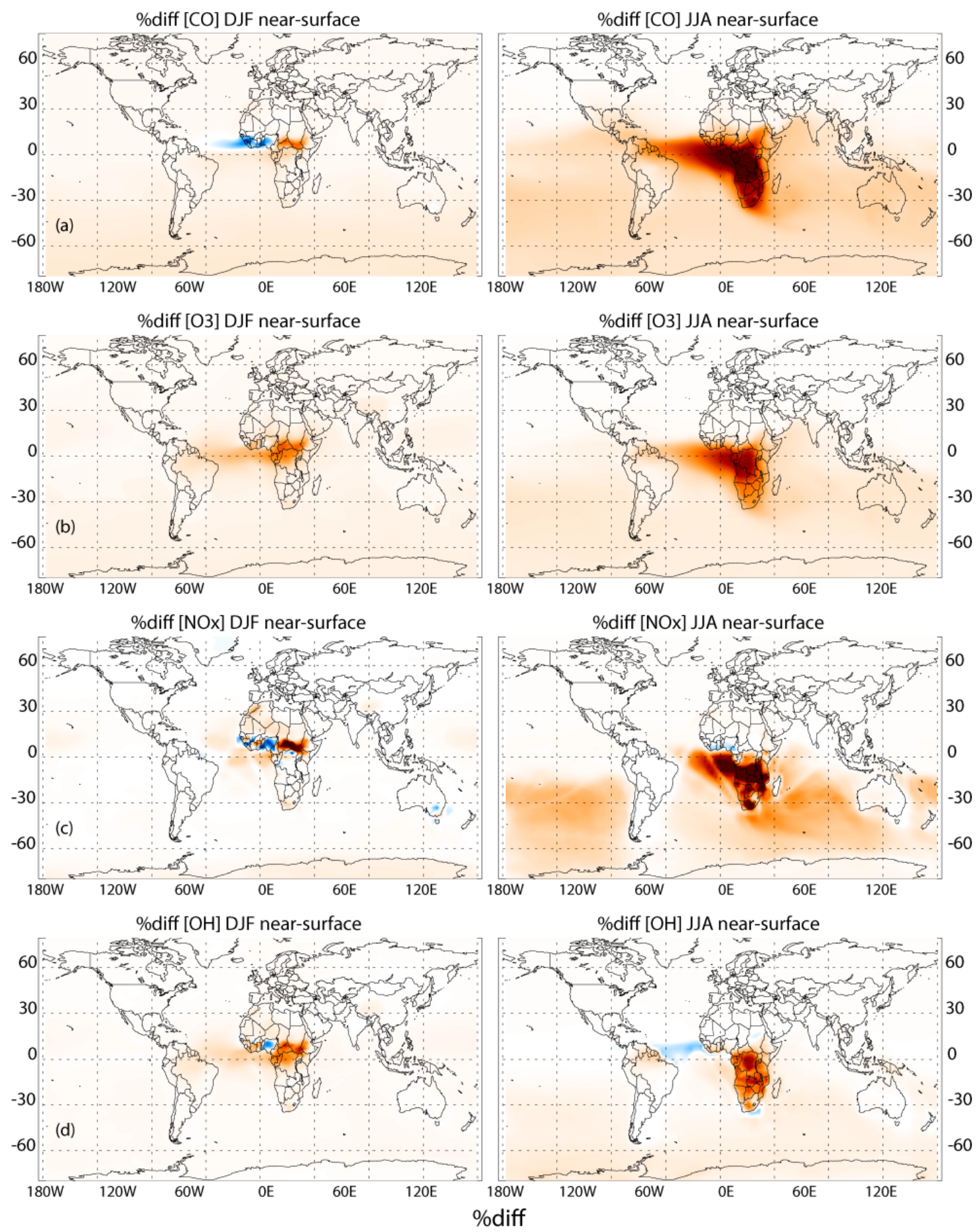

\%diff 


\subsection{Surface Air Quality; Influence of Temporal Distribution and Injection Height}

Recent studies have shown that increasing the update frequency of boreal BB emissions in a CTM can make a significant difference to the simulated effects of $\mathrm{BB}$ on both local and regional air quality [46]. For African BB similar effects have been shown concerning the transport of pollutants in the westerly outflow during JJA [3]. Here we investigate the effect of applying the GFEDv2 8-day emission inventory on near-surface air quality both near the source regions and at global scale. It should be noted that the GFEDv2 8-day inventory is applied for all continents in this instance and not limited to Africa as in some of the other sensitivity studies. For brevity, we limit the discussion to those changes which occur in the tropics and $\mathrm{SH}$.

Figure 6 shows the seasonal differences in near-surface $\mathrm{CO}, \mathrm{O}_{3}, \mathrm{NO}_{\mathrm{x}}$, and $\mathrm{OH}$ between the GFEDv2 and 8-DAY simulations for DJF and JJA. As would be expected from the comparisons of the various BB emission inventories made in Figures 1 and 4, the magnitude of the differences between simulations adopting the different GFEDv2 inventories are considerably smaller than the differences shown between the alternative BB inventories (Figure 5). The variation in integrated monthly emission fluxes between the GFEDv2 monthly and 8-day inventories (Figure 4) imposes a seasonality regarding the effects of increasing the update frequency of the temporal distribution, with the influence during JJA being much larger than during DJF as a result of differences in the seasonally integrated BB emission fluxes. Near regions exhibiting high burning activity (e.g., South America and southern Africa) decreases in $\mathrm{CO}$ and $\mathrm{O}_{3}$ of between $\sim 5$ and $10 \%$ occur for the near-surface, showing that the differences in the monthly emission totals are important over the continents. Seasonal differences also occur in near-surface $\mathrm{CO}$ and $\mathrm{O}_{3}$ at higher latitudes $>60^{\circ} \mathrm{N} / \mathrm{S}$, although are limited to $\pm 2 \%$ due to the much lower regional BB emission fluxes (not shown). Although there is a qualitative agreement in the regional effects around the northern US between our study and that of Chen et al. [46], the impacts in our simulations are much smaller most likely related to the differences in the prescribed injection heights (where $\mathrm{BB}$ emissions are introduced below $800 \mathrm{hPa}$ in Chen et al. [46] compared to below $500 \mathrm{hPa}$ in our simulations). Recent studies have shown that boreal BB emissions are typically lofted well above the boundary layer [47], which supports the recommendations for latitudinally dependant injection height adopted here [11].

Similar comparisons calculated between the GFEDv2 and HIGH-IH simulation (not shown) reveal that the corresponding differences near the tropical BB source regions generally lead to increases of up to $3 \%$ regardless of season. Thus, the regional effect around the BB source regions is the opposite of that shown in Figure 6. In both simulations the majority of the daily BB emissions are introduced into the boundary layer due to the application of the daily burning cycle. It should be noted that the updated injection heights are only applied for the latitude range $30^{\circ} \mathrm{S}-30^{\circ} \mathrm{N}$. Previous modeling studies have shown that, for the boreal regions, BB emissions can be injected directly above the boundary layer, reaching the upper troposphere in some instances [48,49] and affecting regional air quality. For tropical BB the effects are more limited as they do not enter the FT. 
Figure 6. The relative percentage differences in the global near-surface concentrations for (a) $\mathrm{CO}$; (b) $\mathrm{O}_{3}$; (c) $\mathrm{NO}_{\mathrm{x}}$; and (d) $\mathrm{OH}$ for seasons DJF (left) and JJA (right) between GFEDv2 and 8-DAY. The relative differences are calculated as (8-DAY-GFEDv2)/ GFEDv2) $\times 100$.
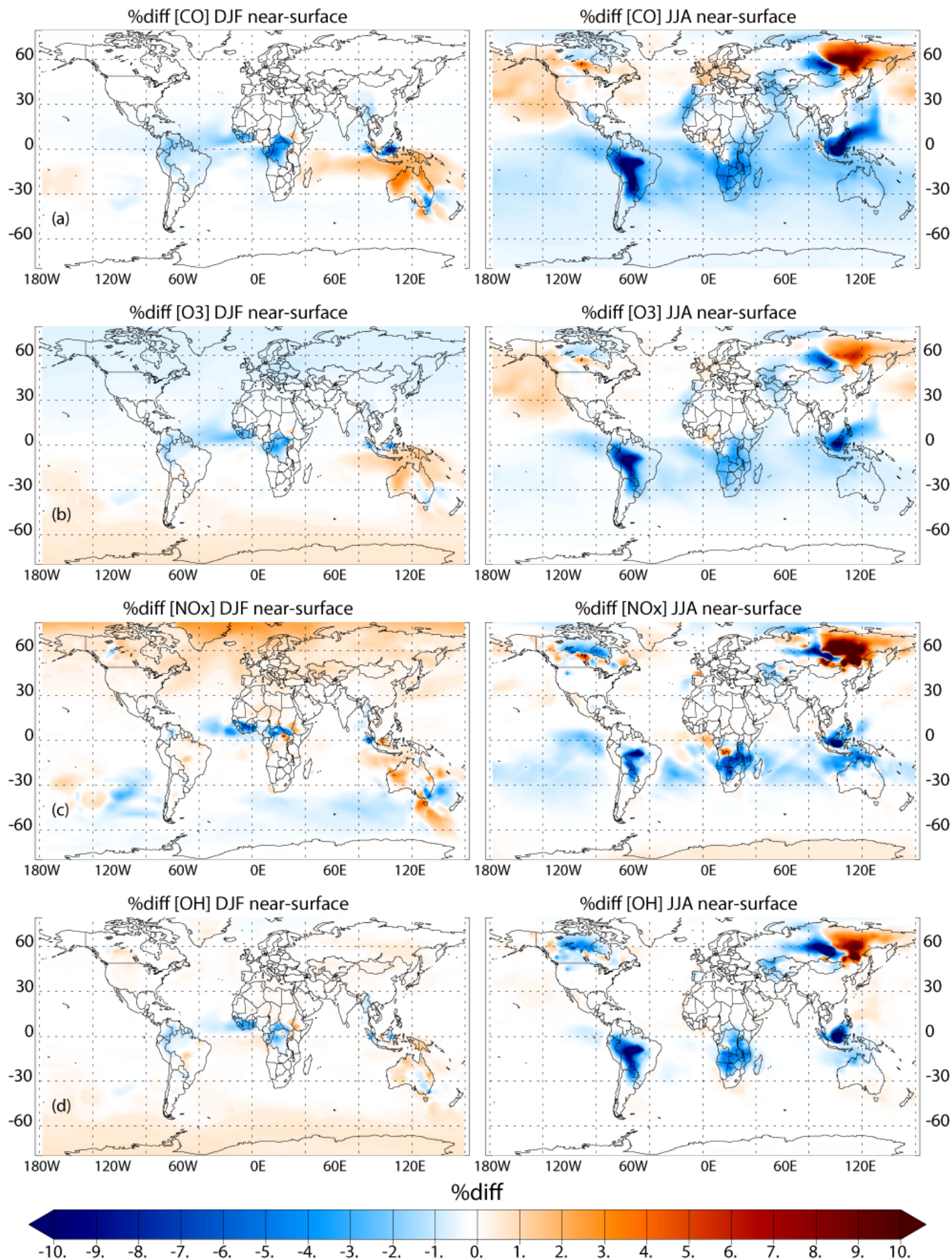
In summary, comparing the distribution of pollutants at the near-surface in the tropics shows that increasing the temporal distribution of BB burning events has a larger, but opposite, effect than increasing the injection height at which the emissions are introduced. This agrees with the findings of previous studies $[3,46]$ although the lack of measurement datasets for near-surface air quality in the tropics means that it is difficult to determine which sensitivity test results in the optimal model performance. However, for the outflow regions, we make comparisons in the following section. Implementing both updates simultaneously would result in some degree of cancellation of effects around the burning regions.

\subsection{Comparison against Observations}

The distribution of $\mathrm{CO}$ and $\mathrm{O}_{3}$ simulated by TM4 in and around Africa has already been assessed in the literature for JJA as compared against a host of different in situ measurement datasets [3,28]. For instance, a recent multi-model study involving TM4 focused on comparisons of CO in the UT above Africa during August 2006 [29]. The main source of CO during this month is BB in southern Africa meaning that such comparisons act as a good indication of the performance of TM4 directly above the BB emission sources. Simulations were performed using the AMMABB emission inventory, similar to those described in this paper. Comparisons of $\mathrm{CO}$ at $215 \mathrm{hPa}$ against satellite observations from the Microwave Limb Sounder (MLS) [50] have shown that TM4 can capture the latitudinal distribution quite well over southern Africa and in the outflow towards the west. When comparing against in situ observations of $\mathrm{CO}$ made in the African UT as part of the MOZAIC in-flight measurement program [51], TM4 shows a maximum at $250 \mathrm{hPa}$ which is located too far north by $6^{\circ}$ and overestimates resident mixing ratios at the maximum by $\sim 20 \mathrm{ppb}$. Similar comparisons made against TM4 simulations using the GFEDv2 emission inventory generally underpredict the MOZAIC measurements between $20^{\circ} \mathrm{S}$ and $20^{\circ} \mathrm{N}$. Therefore neither emission inventory can be considered to be optimal in capturing the measured concentrations of CO into the UT. The transport out of the region is sensitive to the accuracy of the Tietdke convective parameterization [52] employed in TM4 for the description of convective mixing out of the boundary layer. Barret et al. [29] have shown that the Tietdke scheme results in weaker convective mixing than other alternative parameterizations integrated into other CTMs [29]. This has implications regarding the efficiency of long-range transport of trace gases towards the west during JJA as presented here.

In this study we build on these previous studies and examine if TM4 can capture the observed seasonal cycle and the variability in surface mixing ratios in the tropics and SH. For this purpose we make comparisons of co-located model output with ground based flask measurements taken as part of the NOAA ESRL global network [53,54]. Figure 7 shows comparisons of monthly mean mixing ratios from the NONE, GFEDv3 and AMMABB simulations against the corresponding measurements for selected locations in the $\mathrm{SH}$.

The model monthly mean values are calculated using only days where observations were available in order to make a valid comparison. 
Figure 7. The seasonal cycle of surface $\mathrm{CO}$ in Africa and the Southern Hemisphere. The NOAA ESRL measurements stations shown are (Top row) Assekram $\left(23.1^{\circ} \mathrm{N}, 5.3^{\circ} \mathrm{E}\right)$, Ascension Island $\left(7.9^{\circ} \mathrm{S}, 14.4^{\circ} \mathrm{W}\right)$, Crozet Island $\left(46.3^{\circ} \mathrm{S}, 51.5^{\circ} \mathrm{E}\right)$; (Middle row) Seychelles $\left(4.7^{\circ} \mathrm{S}, 55.2^{\circ} \mathrm{E}\right)$, Easter Island $\left(27.2^{\circ} \mathrm{S}, 109.5^{\circ} \mathrm{W}\right)$, American Samoa $\left(14.3^{\circ} \mathrm{S}\right.$, $\left.170.6^{\circ} \mathrm{W}\right)$; (Bottom row) Christmas Island $\left(1.4^{\circ} \mathrm{N}, 157.1^{\circ} \mathrm{W}\right)$, Tierra del Fuego $\left(54.9^{\circ} \mathrm{S}\right.$, $\left.68.5^{\circ} \mathrm{W}\right)$ and Syowa Antarctica $\left(69.0^{\circ} \mathrm{S}, 39.6^{\circ} \mathrm{E}\right)$. The simulations shown are NONE (black), GFEDv3 (red) and AMMABB (blue).
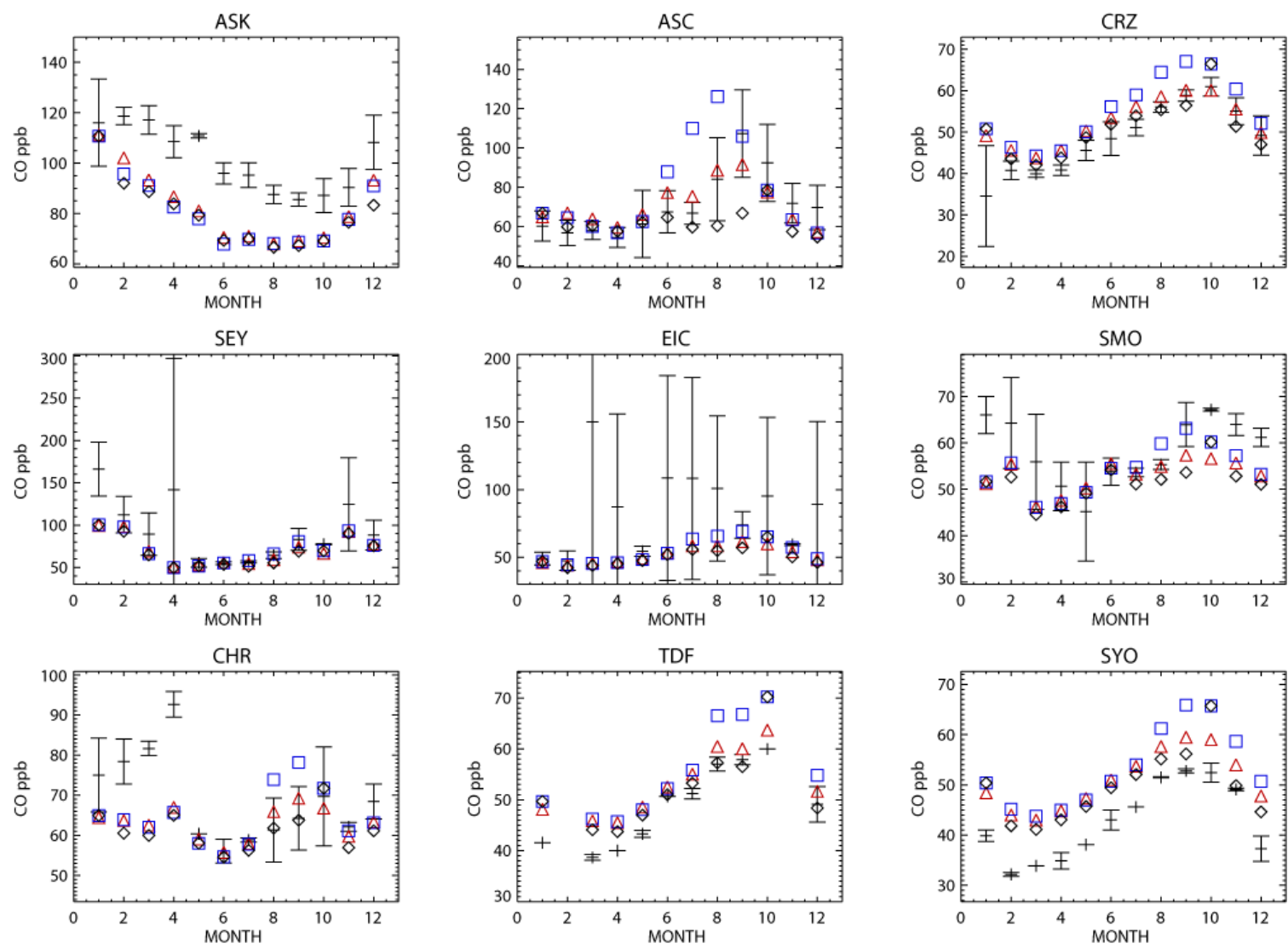

For certain months the $1-\sigma$ deviation of the mean in the observations is much larger than that calculated for the model monthly means (not shown), e.g., at site EIC. This shows that the daily variability seen in the observations is not fully captured by TM4. Potential reasons include the use of monthly emission fluxes and the inadequacies of the ECMWF meteorological dataset in remote regions in the tropics [3]. The only station situated in northern Africa is Asskeram (ASK) in southern Algeria. Here the influence of $\mathrm{BB}$ emissions from the $\mathrm{SH}$ are negligible, again due to blocking of northerly transport by the ITCZ. For stations directly in the outflow (Ascension Island (ASC) to the west and Crozet Island (CRZ) to the east) and towards high southern latitudes (Tierra Del Fuego (TDF) and Syowa (SYO)) there is a significant difference between the various simulations during JJAS. For these months the AMMABB simulation tends to overestimate surface $\mathrm{CO}$ in the outflow by $\sim 20-30 \%$. For the GFEDv3 emission inventory the model captures both the magnitude and phase of the observed seasonal cycles quite well, albeit underestimating during certain months. It is interesting to note that the impact of CO from SH BB can be seen at locations far to the east as American Samoa (SMO), where transport over similar distances has been detected in the FT by the MOPITT instrument [4]. For the other simulations the only discernible difference in the monthly mean mixing 
ratios calculated using the GFEDv2 and GFEDv3 inventories is that GFEDv3 has a marginally higher value at ASC during August (resulting in a small overestimation).

Figure 8 shows the residual calculated between the model monthly mean mixing ratios and ground based observations for the GFEDv2 and 8-DAY simulations at six of the surface stations included in Figure 7. Focusing on selected stations situated in the easterly and westerly outflow regions and at high southern latitudes shows that although the differences are quite small the impact of temporal variability in tropical BB emissions can be seen over large distances. Comparing values it becomes clear that there is generally a better agreement for the 8-DAY run, which has residual values closer to unity during JJAS at most of the stations. That the measurements sites are located in the SH means there is limited impact of West African BB emissions on the comparisons (Figure 5). A similar comparison for the HIGH-IH run (not shown) reveals minimal differences compared with the GFEDv2 simulation. This provides further evidence that the effect of updating the frequency of the temporal distribution is more important than the relatively small variability in the injection heights of tropical $\mathrm{BB}$. Thus, these comparisons show that $\mathrm{BB}$ inventories with high temporal variability (i.e., weekly update frequencies) should be used in preference to those which aggregate burning emissions over an entire month whenever available.

Figure 8. Residual values between the monthly mean $\mathrm{CO}$ mixing ratios at the surface for the GFEDv2 and 8-DAY simulations. The residuals are calculated by dividing the model monthly means by the observational monthly means at selected stations from the NOAA ESRL network. The measurements stations shown are (top row) Seychelles $\left(4.7^{\circ} \mathrm{S}, 55.2^{\circ} \mathrm{E}\right)$, Crozet Island $\left(46.3^{\circ} \mathrm{S}, 51.5^{\circ} \mathrm{E}\right)$; (middle row) Ascension Island $\left(7.9^{\circ} \mathrm{S}, 14.4^{\circ} \mathrm{W}\right)$, Tierra del Fuego $\left(54.9^{\circ} \mathrm{S}, 68.5^{\circ} \mathrm{W}\right)$ and (bottom row) Palmer $\left(64.5^{\circ} \mathrm{S}, 0.4^{\circ} \mathrm{W}\right)$ and Syowa Antarctica $\left(69.0^{\circ} \mathrm{S}\right.$, $39.6^{\circ} \mathrm{E}$ ). The simulations shown are GFEDv2 (blue) and 8-DAY (red).
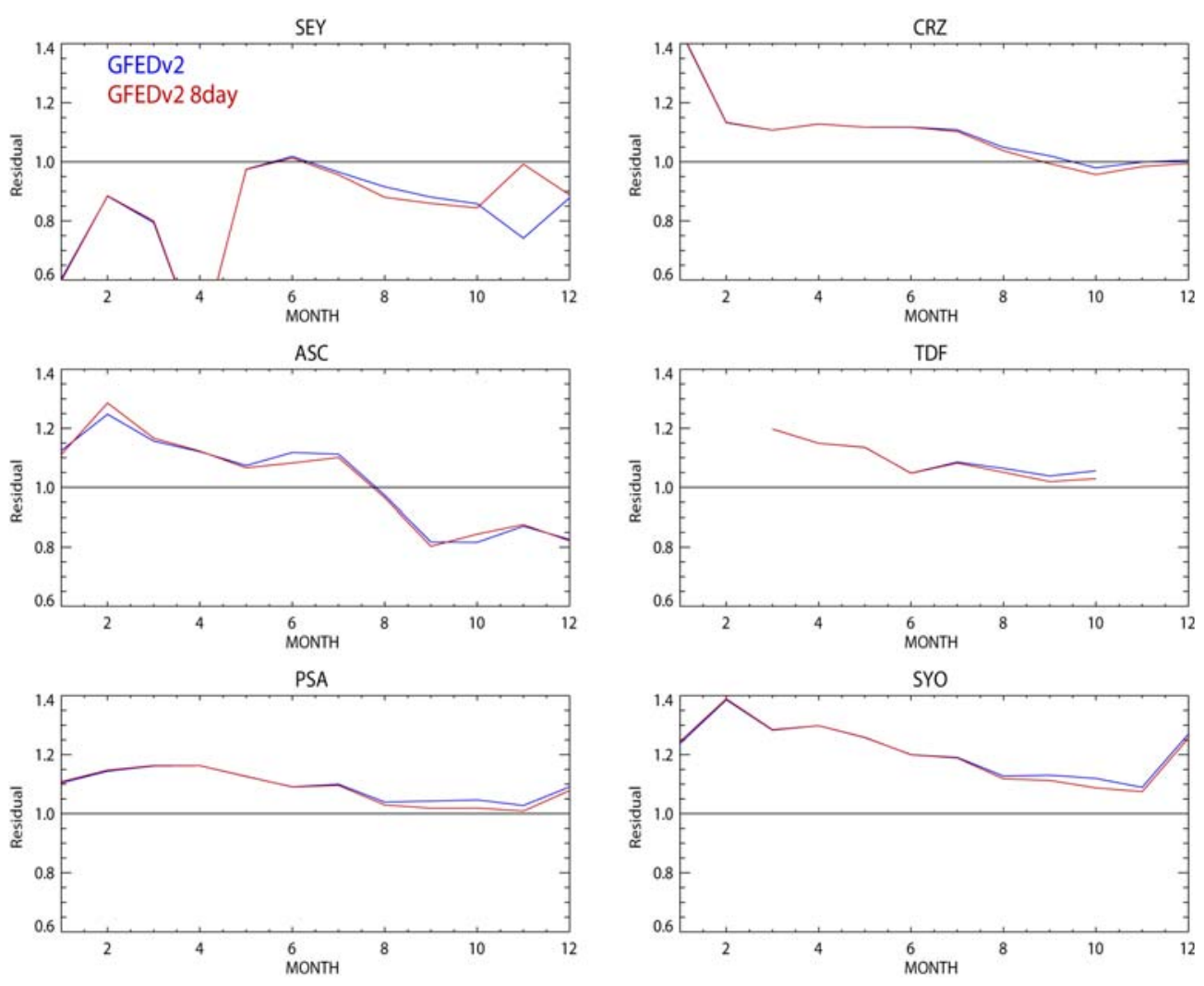


\subsection{Long Range Transport from Africa; Influence of BB Inventory}

To quantify the variability in long range transport out of Africa, Figure 9 shows the seasonal differences in $\mathrm{CO}, \mathrm{O}_{3}, \mathrm{NO}_{\mathrm{x}}$, and $\mathrm{OH}$ between the GFEDv3 and AMMABB simulations in the middle troposphere at $\sim 550 \mathrm{hPa}$. Again the differences are maximal for season JJA, where significantly more $\mathrm{CO}$ and $\mathrm{NO}_{\mathrm{x}}$ is exported outside the tropics into the $\mathrm{SH}$ for the AMMABB simulation, resulting in increases of $\sim 50-70 \%$ in the resident mixing ratios in the FT. The maximal differences occur directly over the burning regions due to strong convective uplift out of the boundary layer, and also along the westerly and easterly outflow pathways. Even though the photo-chemical production efficiency of $\mathrm{OH}$ increases by $\sim 7 \%$ during JJA there is a net decrease in the seasonal mixing ratio in the tropical FT of around $\sim 5 \%$. This is due to the enhanced scavenging by the additional $\mathrm{CO}$ which is lifted out of the boundary layer in the $\mathrm{AMMABB}$ simulation, where $\mathrm{CO}$ is a dominant chemical sink term for $\mathrm{OH}$ under low NOx conditions [55]. Thus the composition of the FT in the $\mathrm{SH}$ is rather sensitive to the $\mathrm{BB}$ emission inventory applied for Africa. The perturbations seen above Oceania also agree with observational evidence published in the literature [4]. It should be noted that convective parameterization in TM4 has been shown to be rather weak over Africa [29] meaning that the effects shown here could be smaller than those captured by other CTMs. We discuss the implications for the variation in the oxidative capacity of the $\mathrm{SH}$ in Section 5.

In a previous study the distribution of $\mathrm{O}_{3}$ in the UT simulated by TM4 has been shown to compare favorably against MOZAIC observations at $\sim 250 \mathrm{hPa}$ for August 2006 when using the AMMABB BB emission inventory [29], although the minimum observed between $5^{\circ} \mathrm{S}-5^{\circ} \mathrm{N}$ is over-estimated by 25-10 ppb. Similar comparisons for simulations using the GFEDv2 BB emission inventory generally lead to an under prediction in the SH of $\sim 10-20 \mathrm{ppb}$. To investigate the agreement at locations further away from the source regions we perform additional comparisons against measurements. Figure 10 shows comparisons of seasonal ozonesonde composites for DJF and JJA at the tropical stations Paramaribo $\left(5.8^{\circ} \mathrm{N}, 55.2^{\circ} \mathrm{W}\right)$, to the west, and La Reunion $\left(21.1^{\circ} \mathrm{S}, 55.5^{\circ} \mathrm{E}\right)$, to the east. Co-located model composites are also shown for NONE, GFEDv3 and AMMABB. Both of these stations are located in the outflow regions where the seasonal variability in tropospheric $\mathrm{O}_{3}$ between the chosen $\mathrm{BB}$ emission inventories is of the order of $\sim 5-15 \%$ (Figure 9). The influence of African BB on tropospheric $\mathrm{O}_{3}$ away from the source regions is highly dependent on the chemical mechanism employed to describe the chemical evolution in the polluted plumes during transport, which typically take days to reach the location of the measurement sites [56]. For stations further south (e.g., Neumayer $\left(70.7^{\circ} \mathrm{S}, 8.3^{\circ} \mathrm{W}\right)$ ) the effects are limited to a few percent and, for brevity, are not shown. The non-linearity associated with tropospheric $\mathrm{O}_{3}$ formation near high emission sources of $\mathrm{NO}_{\mathrm{x}}$ and $\mathrm{NMHC}$ [57] means that the observed differences in $\mathrm{O}_{3}$ in the outflow are not directly scalable to the differences in $\mathrm{BB} \mathrm{NO}_{\mathrm{x}}$ between inventories. 
Figure 9. The relative percentage differences in the global concentrations for (a) $\mathrm{CO}$; (b) $\mathrm{O}_{3}$; (c) $\mathrm{NO}_{\mathrm{x}}$; and (d) $\mathrm{OH}$ between the GFEDv3 and AMMABB simulations for seasons DJF (left) and JJA (right) in the middle troposphere of the atmosphere at $\sim 550 \mathrm{hPa}$. The difference is calculated as (AMMABB-GFEDv3)/GFEDv3.
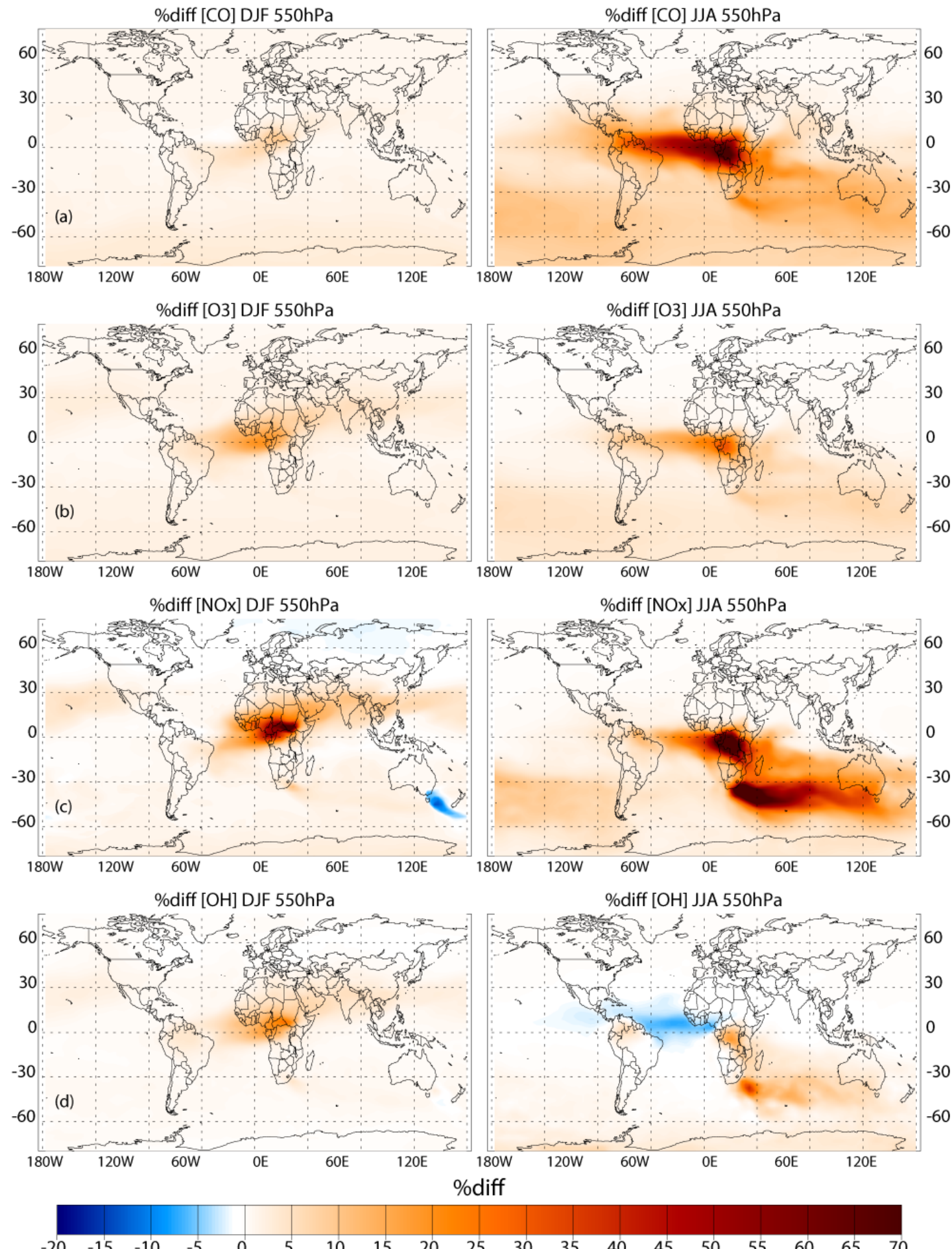
Figure 10. Seasonal comparisons of co-located tropospheric ozone profile composites for seasons DJF (Top) and JJA (Bottom). The soundings stations shown are (Left) Paramaribo $\left(5.8^{\circ} \mathrm{N}, 55.2^{\circ} \mathrm{W}\right)$ and (Right) La Reunion Island $\left(21.1^{\circ} \mathrm{S}, 55.5^{\circ} \mathrm{E}\right)$, with the measurements taken from the SHADOZ database. The black line represents the measurements along with the $1-\sigma$ deviation of the seasonal means, with the number of observations used being shown in the top left of each panel. Three simulations are shown: NONE (blue), GFEDv3 (red) and AMMABB (green).


For Paramaribo African BB influences the lower and middle troposphere during both seasons to the same degree. Even in the absence of African BB the model over predicts the near-surface $\mathrm{O}_{3}$ as a result of TM4 either having a low dry deposition flux over forested regions [58] or an over estimation of local emission sources, which affect mixing ratios in the boundary layer near the measurement site [59]. A further complication is that the measurement site is near the coast, where the diurnal cycle of atmospheric mixing that occurs near the land-sea boundary is difficult to capture in a global model using a rather coarse horizontal resolution. Comparing simulations which include African BB shows that there is a $\sim 15-20 \%$ influence at the eastern coast of South America. Even though the emissions are lofted rapidly into the FT the simulations show effects throughout the tropospheric column. In Africa it has also been shown that the description of transport across the ITCZ by ECMWF operational meteorology is significantly influenced by the frequency of the measurements which are assimilated into the forecasting system [3]. For JJA this leads to an over-estimation of the influence of BB from southern Africa on the lower troposphere over the West African coast for this year in TM4. A similar 
effect seems to be visible at Paramaribo, where the magnitude of the effects is homogenous from the surface to $250 \mathrm{hPa}$, again suggesting too efficient transport of air influenced by African BB into the lower troposphere. Although the AMMABB simulation shows that highest mixing ratios the quality of the agreement is worse (better) in the LT (FT). Therefore it is difficult to use this comparison for placing emphasis on the quality of each BB inventory due to other biases that seem to exist in TM4.

For La Reunion the comparisons show a somewhat different behavior. The location of the measurement site, meteorological variability and seasonality with respect to the location of African $\mathrm{BB}$ in the SH limits the influence of African BB to JJA only. The largest effects occur in the upper troposphere between $300-500 \mathrm{hPa}$. The measurement site is located on a small island and can therefore be seen as representative of the marine boundary layer in the tropical SH. Being situated away from strong emission sources, the gradient of the tropospheric $\mathrm{O}_{3}$ profile is captured relatively well. Comparing simulations shows that the AMMABB emission inventory results in the best comparison of all those shown, where the contribution from Africa $\mathrm{BB}$ is $\sim 13 \%$ to the simulated $\mathrm{O}_{3}$ profile. The differences in the boundary layer are rather minimal showing that the ECMWF meteorology does not transport too much.

Comparing the GFEDv2 and GFEDv3 simulations (not shown) similar to Figure 9 reveals that differences in the resident mixing ratios of $\mathrm{CO}$ and $\mathrm{O}_{3}$ in the FT of between $\sim \pm 2$ and $10 \%$, with the maximal differences again being found directly above the main BB source regions and in the outflow. The differences in the background are limited to a few percent. As for the near-surface, there is strong seasonality in the simulated differences with decreases (increases) during DJF (JJA) as governed by the seasonality in African BB.

\subsection{Long Range Transport from Africa; Influence of Temporal Distribution and Injection Height}

Figure 11 shows the seasonal differences in long range transport at $\sim 550 \mathrm{hPa}$ when comparing the GFEDv2 and 8-day simulations, similar to that shown in Figure 9. Again, the differences are small $(\sim 2-5 \%)$ compared to the differences shown between the AMMABB and GFEDv3 BB emission inventories and there is a pronounced seasonality in the effects. There is also a latitudinal dependency in the perturbations related to the respective increases and decreases in the monthly aggregated BB emissions of $\mathrm{CO}$ and $\mathrm{NO}_{\mathrm{x}}$ between the two simulations for various regions (not shown). For DJF the differences are limited to the order of $\pm 2 \%$ for tropospheric $\mathrm{CO}$ and $\mathrm{O}_{3}$, where a strong signature for $\mathrm{CO}$ is seen in and around Indonesia. For JJA the largest impact is in the SH, related to burning in South America, southern Africa and Indonesia. The largest differences occur for $\mathrm{NO}_{\mathrm{x}}$, where the amount transported away from the source regions decreases due to less PAN being transported into the region (not shown). One interesting feature is the decrease in the mixing ratio of $\mathrm{OH}$ in spite of a corresponding decrease in the mixing ratio of $\mathrm{CO}$. Analyzing the chemical budget terms shows that the there is enhanced loss of $\mathrm{OH}$ via the oxidation of $\mathrm{O}_{3}$, methyl peroxide $\left(\mathrm{CH}_{3} \mathrm{OOH}\right), \mathrm{CH}_{4}$ and $\mathrm{H}_{2}$ in the 8-day run, which compensates for the reduced scavenging of $\mathrm{OH}$ by $\mathrm{CO}$.

Finally, similar comparisons made between the GFEDv2 and HIGH-IH simulation (not shown) reveal that increases of a few percent occur directly above the most active burning regions due to venting from the boundary layer but effects in the outflow are rather negligible. This finding supports the conclusion drawn in Section 4.2, i.e., that increasing the temporal distribution of tropical BB 
emissions has a more pronounced effect on tropical and $\mathrm{SH}$ tropospheric composition than increasing the injection height.

Figure 11. The relative percentage differences in the global concentrations for (a) $\mathrm{CO}$; (b) $\mathrm{O}_{3}$; (c) $\mathrm{NO}_{\mathrm{x}}$; and (d) $\mathrm{OH}$ between the GFEDv2 and 8-DAY simulations for seasons DJF (left) and JJA (right) in the middle troposphere of the atmosphere at $\sim 550 \mathrm{hPa}$. The difference is calculated as (8-DAY-GFEDv2)/GFEDv2.
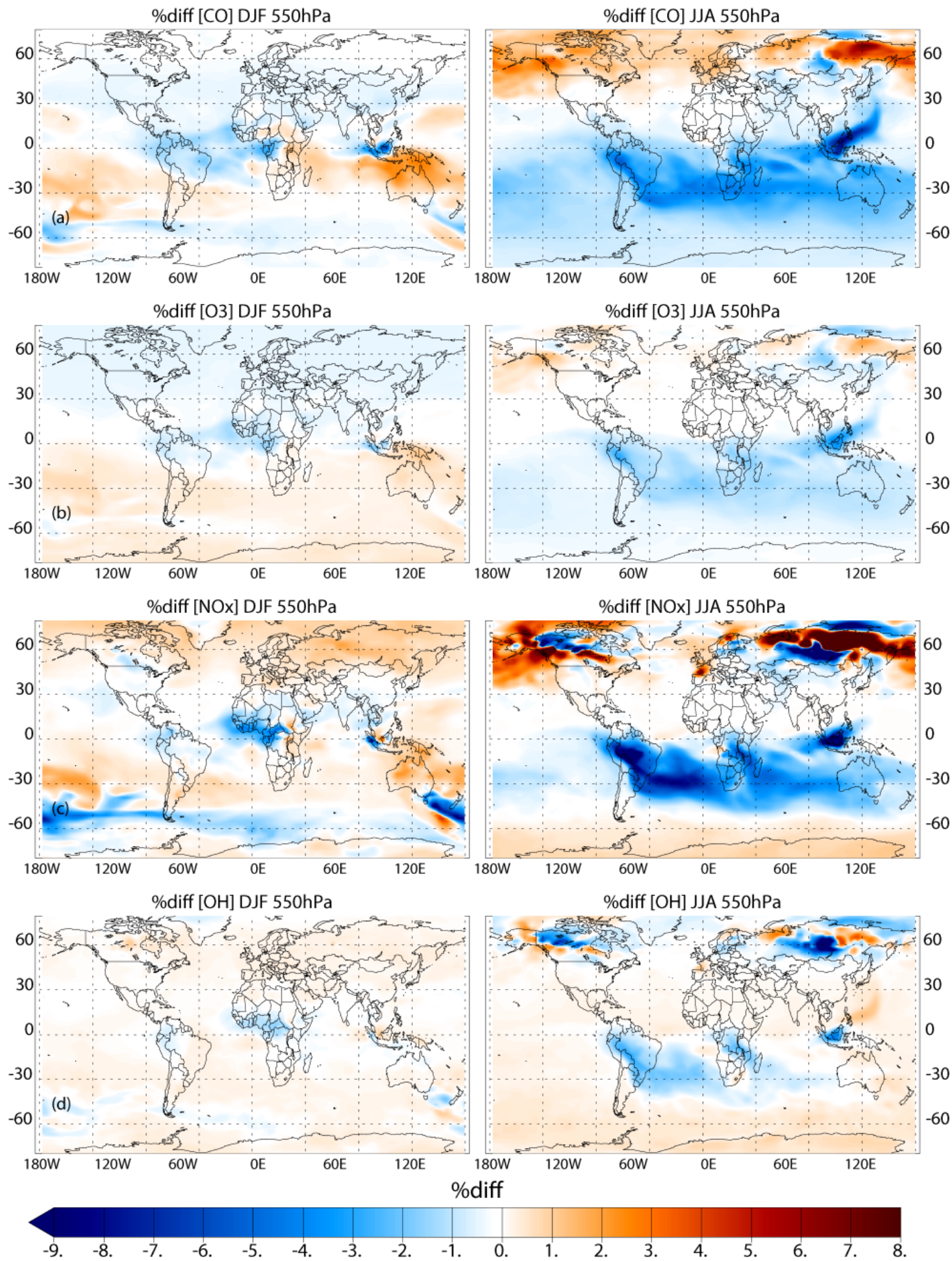


\section{Changes to Global Burdens and Tropospheric Lifetimes}

The large variability in the estimates of trace gas emissions contained in the different bottom-up BB emission inventories for Africa shown in Table 2 has the potential to significantly impact the burdens and lifetimes of the ubiquitous trace gas species, $\mathrm{O}_{3}, \mathrm{CO}$ and $\mathrm{CH}_{4}$. In order to investigate the perturbations introduced we use a set of diagnostics which have been defined for assessing the performance of CTMs during multi-model intercomparison studies [16]. For brevity we limit the discussion to the changes introduced by the different BB emission estimates, with the differences due to temporal variability and injection height being rather small in comparison and therefore of lesser interest.

For tropospheric $\mathrm{O}_{3}$ the variability in the burden (BO3), tropospheric lifetime ( $\left.\tau \mathrm{O} 3\right)$ and net annual production terms $\left(\mathrm{pO}_{3}\right)$ are given in Table 4 for the different $\mathrm{BB}$ emission inventories. The percentage differences that are given are calculated with respect to the NONE simulation. Here we define a climatological tropopause [60] throughout the analysis which ensures that the mass of the troposphere remains constant for all simulations therefore allowing a valid comparison of tropospheric burdens and lifetimes.

Table 4. The variability in the global tropospheric burden and lifetime of $\mathrm{O}_{3}$ during 2006 when adopting the different BB emission inventories for Africa. Also shown is the total global in situ chemical production of $\mathrm{O}_{3}$. The climatological tropopause of Lawrence et al. [60] is used to define the troposphere throughout. The relative percentage changes of tropospheric lifetimes and global burdens as compared to the NONE simulation are given in parenthesis.

\begin{tabular}{cccc}
\hline & $\mathbf{B O}_{\mathbf{3}}\left(\mathbf{T g ~ \mathbf { O } _ { 3 }}\right)$ & $\mathbf{O}_{\mathbf{3}}$ Lifetime (days) & $\mathbf{p O}_{\mathbf{3}}\left(\mathbf{T g ~ \mathbf { O } _ { 3 }}\right)$ \\
\hline NONE & 317.7 & 24.1 & 4328.1 \\
GFEDv2 & $323.0(+1.7)$ & $23.6(-1.9)$ & $4500.3(+4.0)$ \\
GFEDv3 & $323.2(+1.8)$ & $23.7(-1.6)$ & $4492.5(+3.8)$ \\
AMMABB & $332.2(+4.6)$ & $23.3(-3.0)$ & $4641.8(+7.2)$ \\
AMMABB_LOWNOX & $325.7(+2.5)$ & $23.6(-1.9)$ & $4555.2(+5.2)$ \\
\hline
\end{tabular}

The introduction of African BB (as defined in the GFEDv2, GFEDv3 and AMMABB simulations) increases $\mathrm{BO}_{3}$ between 1.7 and 4.6\%, resulting in a mean $\mathrm{BO}_{3}$ of $326.1 \pm 5.3 \mathrm{Tg} \mathrm{O}_{3}$ (with an associated uncertainty of $\sim 1.6 \%$ ). The corresponding change in $\tau \mathrm{O} 3$ is from $-1.9 \%$ to $-3.0 \%$, resulting in a mean $\tau \mathrm{O} 3$ of $23.5 \pm 0.2$ days (with an associated uncertainty of $\sim 0.9 \%$ ). The corresponding differences in $\mathrm{BCO}, \tau \mathrm{CO}$, and $\tau \mathrm{CH} 4$ are given in Table 5, along with the total mass of $\mathrm{CH}_{4}$ that is oxidized in each simulation. For $\mathrm{CH}_{4}$ the total mass that is oxidized is equal to the amount oxidized by $\mathrm{OH}$, with a fixed soil sink of $30 \mathrm{Tg} \mathrm{yr}^{-1}$ and a stratospheric sink of $40 \mathrm{Tg}^{-1}$, as outlined in Stevenson et al. [16]. Comparing values reveals that African $\mathrm{BB}$ decreases the global lifetimes of both trace gases across the range of $\mathrm{CO} / \mathrm{N}$ ratios contained in the different $\mathrm{BB}$ inventories ( 43-69), i.e., regardless of the seasonal $\mathrm{CO}$ emission flux. This gives mean atmospheric lifetimes across all three $\mathrm{BB}$ inventories of $\tau \mathrm{CO}=53.4 \pm 0.4$ days and $\tau \mathrm{CH} 4=8.70 \pm 0.02$ years, which translates to an uncertainty of $\sim 0.7 \%$ and $\sim 0.2 \%$, respectively. 
Table 5. The global tropospheric burdens and lifetimes of $\mathrm{CO}$, and $\mathrm{CH}_{4}$ for the different BB emission inventories adopted for Africa during 2006.

\begin{tabular}{ccccc}
\hline & $\begin{array}{c}\text { BCO } \\
\text { (Tg CO) }\end{array}$ & $\begin{array}{c}\text { CO Lifetime } \\
\text { (days) }\end{array}$ & $\begin{array}{c}\text { Mass CH } \\
\text { Oxidised }\end{array}$ & $\begin{array}{c}\mathbf{C H}_{\mathbf{4}} \text { Lifetime } \\
\text { (years) }\end{array}$ \\
\hline NONE & 302.6 & 54.4 & 499.4 & 8.75 \\
GFEDv2 & $320.8(+6.0)$ & $53.6(+1.5)$ & $501.8(+0.5)$ & $8.72(-0.4)$ \\
GFEDv3 & $321.2(+6.1)$ & $53.6(+1.5)$ & $502.1(+0.5)$ & $8.71(-0.5)$ \\
AMMABB & $332.2(+9.9)$ & $52.9(+2.8)$ & $504.3(+1.0)$ & $8.68(-0.8)$ \\
AMMABB_LOWNOX & $339.1(+12.0)$ & $54.3(+0.2)$ & $495.1(-0.9)$ & $8.82(+0.8)$ \\
\hline
\end{tabular}

Increasing $\mathrm{NO}_{\mathrm{x}}$ emissions cause an associated increase in $\mathrm{pO}_{3}$, although a moderating constraint on the variability in both $\mathrm{pO}_{3}$ and $\mathrm{BO}_{3}$ is the enhanced loss of reactive nitrogen via wet deposition as nitric acid ( $\sim 1 \mathrm{Tg} \mathrm{N} \mathrm{yr}^{-1}$ extra when adopting the AMMA BB inventory). Thus the oxidative capacity of the global troposphere is enhanced as a result of African BB.

The uncertainty associated with the mean $\tau \mathrm{CH} 4$ is significant due to the relatively modest increases which occur in the yearly growth rate of fractions of a percent [20], where the variability in the mass of $\mathrm{CH}_{4}$ oxidized across all simulations translates to a variability of $\pm 0.25 \mathrm{ppbv} \mathrm{yr}^{-1}$ in the growth rate. The reduction in $\tau \mathrm{CH} 4$ is largest for $\mathrm{AMMABB}$ which may be counterintuitive because it also exhibits the highest $\mathrm{CO}$ emissions ( $c f$. Table 2). From the $\mathrm{CO}$ consumption argument [21] one would expect an increase in $\tau \mathrm{CH} 4$ due to the increased scavenging of $\mathrm{OH}$ by $\mathrm{CO}$ in the tropics, where the majority of $\mathrm{CH}_{4}$ is oxidized. The AMMABB_LOWNOX simulation shows that increases in $\tau \mathrm{CH} 4$ are only observed if the $\mathrm{CO} / \mathrm{N}$ ratio is relatively high $(\sim 90)$, which reduces the chemical production of ozone as shown in Table 4. Such high $\mathrm{CO} / \mathrm{N}$ ratios are typically associated with peat burning, charcoal production or animal waste burning [6] and thus should be considered an upper limit in terms of realistic $\mathrm{CO} / \mathrm{N}$ ratios. To show the sensitivity of global tropospheric composition to the $\mathrm{CO} / \mathrm{N}$ ratio the annual zonal mean differences between the AMMABB and AMMABB_LOWNOX simulations are shown in Figure 12. That there is a simultaneous increase in $\mathrm{CO}$ and decrease in $\mathrm{OH}$ under low $\mathrm{NO}_{\mathrm{x}}$ conditions indicates that there is less oxidation capacity in the troposphere for the oxidation of $\mathrm{CH}_{4}$ resulting in a subsequent increase in its atmospheric lifetime.

Therefore, some mitigation of the effects of high $\mathrm{CO}$ emissions from $\mathrm{BB}$ occurs due to the associated increase in $\mathrm{NO}_{\mathrm{x}}$ (and thus $\mathrm{O}_{3}$ and $\mathrm{OH}$ ). It cannot be expected that the high $\mathrm{CO} / \mathrm{N}$ ratios defined in the AMMABB_LOWNOX simulation would occur on a continental scale therefore it is likely that increases in $\tau \mathrm{CH} 4$ occur regardless of the inter-annual variability in $\mathrm{BB}$ emissions that originate from Africa. It should be noted that the feedback on photolysis rates due to smoke and aerosol particles is not accounted for in these simulations, but are expected to decrease the photo-chemical production of tropospheric $\mathrm{O}_{3}$ in the lower troposphere, thus allowing more $\mathrm{CO}$ to be transported out of the region. 
Figure 12. The relative percentage differences in the zonal annual mean concentrations for (a) $\mathrm{CO}$; (b) $\mathrm{O}_{3}$; (c) $\mathrm{NO}_{x}$; and (d) $\mathrm{OH}$ between the AMMABB and AMMABB_LOWNOX simulations. The differences are calculated as (AMMABB_LOWNOX-AMMABB)/AMMABB $\times 100$.
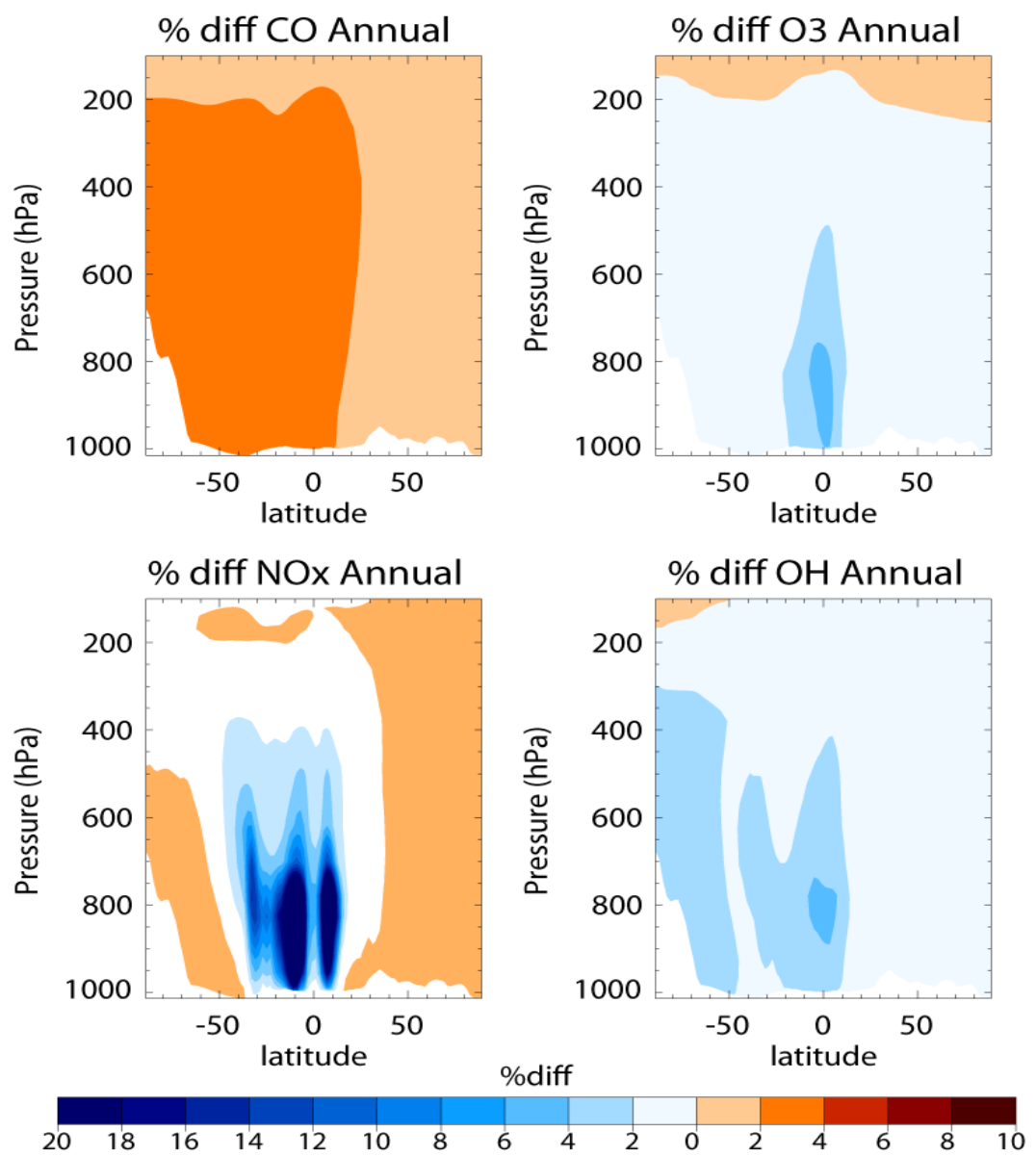

For Africa, most burning is associated with either savannah and grasslands or woodlands, whose estimated $\mathrm{CO} / \mathrm{N}$ ratios are 28.8 and 37.0, respectively [6]. The ratios given in Table 3 can be considered aggregates across a wide variety of different vegetation types for the African region, as shown by the regional variability in $\mathrm{CO} / \mathrm{N}$ ratios shown in Figures 3 and 4 . Recently van Leeuwen and van der Werf [61] have shown that when accounting for environmental variables such as precipitation and temperature, $\mathrm{CO}$ emissions could be higher for savanna and grasslands per $\mathrm{Kg}$ biomass burned significantly impacting emission ratios, although measurements during peak burning periods are necessary to constrain values. In this study we have shown that the global effect of such enhancements would be to increase $\mathrm{BCO}$ and $\mathrm{BO} 3$ by a few percent, whilst decreasing the atmospheric lifetimes of long-lived trace species.

\section{Conclusions}

In this study we have investigated the sensitivity of atmospheric composition in the tropics and Southern Hemisphere towards the biomass burning emission inventory adopted for African biomass burning (namely the GFEDv2, GFEDv3 and AMMABB inventories). Comparing the monthly emission totals for the African continent between the different biomass burning inventories for 2006 
shows that the intensity, location and associated $\mathrm{CO} / \mathrm{N}$ ratios of large scale biomass burning events vary significantly, although the seasonality between inventories is rather similar. For the most active burning season of June-July-August-September this leads to differences of $>100 \%$ in the monthly emission fluxes from Africa. When comparing the GFEDv2 monthly and 8-day emission inventories the integrated monthly emission estimates vary by $\pm 2 \mathrm{Gg}$ and $\pm 0.2 \mathrm{Tg}$ for nitrogen oxides and carbon monoxide (CO), respectively. These differences are introduced as a result of increasing the temporal resolution of the burning events, although the annual emission flux remains approximately equal. The spatial distribution of burning events within Africa is also highly variable when comparing different inventories, especially for the north of the Equator during the boreal winter.

Applying the different biomass burning emission inventories in a 3D global chemistry-transport model leads to significant differences in the near-surface ozone $\left(\mathrm{O}_{3}\right)$ and $\mathrm{CO}$, especially during June-July-August in the Southern Hemisphere (SH). When comparing the simulations which adopt the GFEDv3 and AMMABB emission inventories, differences in near-surface $\mathrm{O}_{3}$ and $\mathrm{CO}$ of $\sim 50-90 \%$ occur during June-July-August near the source regions. In the remote SH differences are of the order of $\sim 5-15 \%$. Increasing the update frequency of the temporal distribution of the burning events from monthly to every 8 days shows decreases of between $\sim 0$ and $10 \%$ for near-surface $\mathrm{O}_{3}$ and $\mathrm{CO}$ near the source regions during both seasons. More modest changes of a few percent occur for the outflow regions. This occurs due to both the changes in the geographic variability of the most intense fires and small differences in the total monthly emission fluxes as defined between inventories. Increasing the injection heights at which trace gas emission from fires are introduced in the tropics $\left(30^{\circ} \mathrm{S}-30^{\circ} \mathrm{N}\right)$ results in differences of a few percent limited to regions which exhibit the most intense fires, as found in the literature.

For the long range transport of gases out of Africa substantial differences of $\sim 50-70 \%$ in the resident mixing ratios of $\mathrm{CO}$ and $\mathrm{NO}_{\mathrm{x}}$ are simulated in the outflow regions at $\sim 550 \mathrm{hPa}$, which has a significant impact of the atmospheric burdens of these trace species in the SH. A comparison of the monthly mean mixing ratios for $\mathrm{CO}$ from the simulations against ground-based flask measurements shows that the AMMABB inventory tends to overestimate background concentrations during June-July-August-September, with the GFEDv3 emission inventory showing the best correlation. For tropospheric $\mathrm{O}_{3}$ comparisons with composites of tropical ozone soundings taken at locations to the east of Africa show that the AMMABB emission inventory shows a better agreement for the middle and upper troposphere, although this is also dependant on both the chemical mechanism which is employed, the efficiency of the convective and advective mixing and the accuracy of the meteorological data used to drive the chemistry-transport model.

The influence of Africa biomass burning on the atmospheric burdens of $\mathrm{CO}$ and $\mathrm{O}_{3}$ results in increases of between $6.0-12.0 \%$ and $1.9-3.0 \%$ across inventories, respectively. This introduces an associated uncertainty into the total tropospheric burdens of $\sim 1.6 \%$ and $\sim 0.9 \%$, respectively. For the atmospheric lifetimes of $\mathrm{CO}, \mathrm{O}_{3}$ and $\mathrm{CH}_{4}$ the values are $53.4 \pm 0.4$ days, $23.5 \pm 0.2$ days and $8.70 \pm 0.2$ years are calculated, respectively, with an associated uncertainty of $\sim 0.9 \%, \sim 0.7 \%$ and $\sim 0.2 \%$. Decreases in $\tau \mathrm{CH} 4$ occur across all $\mathrm{BB}$ inventories regardless of the differences in the total $\mathrm{CO}$ emitted from African BB. This is due to the associated differences in the $\mathrm{CO} / \mathrm{N}$ ratio being rather small between the inventories on the horizontal resolution employed for the study. Thus the increase in the $\mathrm{CO}$ emission is partially mitigated by the simultaneous increase in the oxidative capacity around the 
source regions and, subsequently, in the outflow. Only when the $\mathrm{CO} / \mathrm{N}$ ratio exceeds $\sim 90$ does the increase in the tropospheric $\mathrm{CO}$ burden result in decreases in the lifetime of $\mathrm{CH}_{4}$. This has important implications when explaining the relationship between the inter-annual variability in the global $\mathrm{CH}_{4}$ growth rate and the inter-annual variability in BB emissions from Africa.

\section{References}

1. Thompson, A.M.; Witte, J.C.; Oltmans, S.J.; Schmidin, F.J.; Logan, J.A.; Fujiwara, M.; Kirchhoff, V.W.J.H.; Posny, F.; Coetzee, G.J.R.; Hoegger, B.; et al. Southern Hemisphere Additional Ozonesondes (SHADOZ) 1998-2000 tropical ozone climatology: 2. Tropospheric variability and the zonal wave-one. J. Geophys. Res. 2003, 108, 8241.

2. Ziemke, J.R.; Chandra, S; Duncan, B.N.; Schoeberl, M.R.; Torres, O.; Damon, M.R.; Bhartia, P.K. Recent biomass burning in the tropics and related changes in tropospheric ozone. Geophys. Res. Lett. 2009, 36, L15819, doi:10.1029/2009GL039303.

3. Williams, J.E.; Scheele, M.P.; van Velthoven, P.F.J.; Thouret, V.; Saunois, M.; Reeves, C.E.; Cammas, J.-P. The influence of biomass burning and transport on tropospheric composition over the tropical Atlantic Ocean and Equatorial Africa during the West African Monsoon in 2006. Atmos. Phys. Chem. 2010, 10, 9797-9817.

4. Edwards, D.P.; Emmons, L.K.; Gille, J.C.; Chu, A.; Attié, J.-L.; Wood, S.W.; Haywood, J.; Deeter, M.N.; Massie, S.T.; Ziskin, D.C.; et al. Satellite-observed pollution from Southern Hemisphere biomass burning, J. Geophys. Res. 2006, 111, D14312, doi:10.1029/2005JD006655.

5. Jain. A.K. Global estimation of $\mathrm{CO}$ emissions using three sets of satellite data for burned area. Atmos. Environ. 2007, 41, 6931-6940.

6. van der Werf, G.R.; Randerson, J.T.; Giglio, L.; Collatz, G.J.; Mu, M.; Kasibhatla, P.S.; Morton, D.C.; DeFries, R.S.; Jin, Y.; van Leeuwen, T.T. Global fire emissions and the contribution of deforestation, savanna, forest, agricultural, and peat fires (1997-2009). Atmos. Chem. Phys. 2010, 10, 11707-11735.

7. Liousse, C.; Andreae. M.O.; Artaxo, P.; Barbosa, P.; Cachier, H.; Grégoire, J.-M.; Hobbs, P.; Lavoué, D.; Mouillot, F.; Penner, J.; et al. Deriving global quantitative estimates for spatial and temporal distributions of biomass burning emissions. In Emissions of Atmospheric Trace Compounds; Granier, C., Artaxo, P., Reeves, C., Eds.; Kluwer Academic Publishers: Dordrecht, The Netherlands, 2004; p. 544.

8. van der Werf, G.R.; Randerson, J.T.; Giglio, L.; Collatz, G.J.; Kasibhatla, P.S.; Arellano, A.F., Jr. Interannual variability in global biomass burning emissions from 1997 to 2004. Atmos. Chem. Phys. 2006, 6, 3423-3441.

9. Liousse, C.; Guillaume, B.; Grégoire, J.-M.; Mallet, M.; Galy, C.; Pont, V.; Akpo, A.; Bedou, M.; Castéra, P.; Dungall, L.; et al. Updated African biomass burning emission inventories in the frame of the AMMA-IDAF program, with an evaluation of combustion aerosols. Atmos. Phys. Chem. 2010, 10, 9631-9646.

10. Stroppiana, D.; Brivio, P.A.; Grégoire, J.-M.; Liousse, C.; Guillaume, B.; Granier, C.; Mieville, A.; Chin, M.; Pétron, G. Comparison of global inventories of $\mathrm{CO}$ emissions from biomass burning derived from remotely sensed data. Atmos. Chem. Phys. 2010, 10, 12713-12189. 
11. Dentener, F.; Kinne, S.; Bond, T.; Boucher, O.; Cofala, J.; Generoso, S.; Ginoux, P.; Gong, S.; Hoelzemann, J.J.; Ito, A.; et al. Emissions of primary aerosol and precursor gases in the years 2000 and 1750 prescribed data-sets for Aerocom. Atmos. Chem. Phys. 2006, 6, 4321-4344.

12. val Martin, M.; Logan, J.A.; Kahn, R.A.; Leung, F.-Y.; Nelson, D.L.; Diner, D.J. Smoke injection heights from fires in North America: Analysis of 5 years of satellite observations. Atmos. Chem. Phys. 2010, 10, 1491-1510.

13. Labonne, M.; Breon, F.-M.; Chavallier, F. Injection height of biomass burning aerosols as seen from a spaceborne lidar. Geophys. Res. Letts. 2007, 34, L11806, doi:10.1029/2007GL029311.

14 Tosca, M.G.; Randerson, J.T.; Zender, C.S.; Nelson, D.L.; Diner, D.J.; Logan, J.A. Dynamics of fire plumes and smoke clouds associated with peat and deforestation fires in Indonesia. J. Geophys. Res. 2011, 111, D08207, doi:10.1029/2010JD015148.

15. Shindell, D.T.; Faluvegi, F.; Stevenson, D.S.; Krol, M.C.; Emmons, L.K.; Lamarque, J.-F.; Pétron, G.; Dentener, F.J.; Ellingsen, K.; Schultz, M.G.; et al. Multimodel ensemble simulations of carbon monoxide: Comparison with observations and projected near-future changes. J. Geophys. Res. 2006, 111, D08301.

16. Stevenson, D.S.; Dentener, F.J.; Schultz, M.G.; Ellingsen, K.; van Noije, T.P.C.; Wild, O.; Zeng, G.; Amann, M.; Atherton, C.S.; Bell, N.; et al. Multimodel ensemble simulations of present-day and near-future tropospheric ozone. J. Geophys. Res. 2006, 111, D08301.

17. Duncan, B.N.; West, J.J.; Yoshida, Y.; Fiore, A.M.; Ziemke, J.R. The influence of European pollution on ozone in the Near East and northern Africa. Atmos. Chem. Phys. 2008, 8, 2267-2283.

18. Flanningan, M.D.; Krawchuk, M.A.; de Groot, W.J.; Wotton, B.M.; Gowman, L.M. Implications of changing climate for global wildland fire. Int. J. Wild. Fire 2009, 18, 483-507.

19. Duncan, B.N.; Bey, I.; Chin, M.; Mickley, L.J.; Fairlie, T.D.; Martin, R.V.; Matsueda, H. Indonesian wildfires of 1997: Impact on Tropospheric Chemistry. J. Geophys. Res. 2003, 108, 4458, doi:10.1029/2002JD003195.

20. Simpson, I.J.; Rowland, F.S.; Meinardi, S.; Blake, D.R. Influence of biomass burning during recent fluctuations in the slow growth of global tropospheric methane. Geophys. Res. Lett. 2006, 33, L22808, doi:10.1029/2006GL027330.

21. Bousquet, P.; Ciais, P.; Miller, J.B.; Dlugokencky, E.J.; Hauglustaine, D.A.; Prigent, C.; van der werf, G.R.; Peylin, P.; Brunke, E.-G.; Carouge, C.; et al. Contribution of anthropogenic and natural sources to atmospheric methane variability. Nature 2006, 443, 439-443.

22. Karlsdóttir, S.B.; Isaksen, I.S.A. Changing methane lifetime: Possible cause for reduced growth. Geophys. Res. Lett. 2000, 27, 93-96.

23. Dalsøren, S.B.; Isaksen, I.S.A. CTM study of changes in tropospheric hydroxyl distribution 1990-2001 and its impact on methane. Geophys. Res. Lett. 2006, 33, doi:10.1029/2006GL027295.

24. Houweling, S.; Dentener, F.J.; Lelieveld, J. The impact of non-methane hydrocarbon compounds on tropospheric photochemistry. J. Geophys. Res. 1998, 103, 10673-10696.

25. Williams, J.E.; van Noije, T.P.C. On the Upgrading of the Modified Carbon Bond Mechanism IV for Use in Global Chemistry Transport Models, 2008; KNMI Scientific Report WR 2008-02; KNMI: De Bilt, The Netherlands, 2008; p. 64. Available online: http://www.knmi.nl/bibliotheek/ knmipubWR/WR2008-02.pdf (accessed on 7 February 2012). 
26. Landgraf, J; Crutzen, P.J. An efficient method for online calculations of photolysis and heating rates. J. Atmos. Sci. 1998, 55, 863-878.

27. Krol, M.C.; van Weele, M. Implications of variations in photodissociation rates for global tropopsheric chemistry. Atmos. Environ. 1997, 31, 1257-1273.

28. Williams, J.E.; Scheele, R.; van Velthoven, P.; Bourar, I.; Law, K.; Josse, B.; Peuch, V.-H.; Yang, X.; Pyle, J.; Thouret, V.; et al. S. Global chemistry simulations in the AMMA Multimodel Intercomparison project. Bull. Am. Meteor. Soc. 2010, 91, 611-624.

29. Barret, B.; Williams, J.E.; Bouarar, I.; Yang, X.; Josse, B.; Law, K.; Pham, M.; le Flochmoën, E.; Liousse, C.; Peuch, V.-H.; et al. Impcat of West African Monsoon convective transport and lightning $\mathrm{NO}_{\mathrm{x}}$ production upon the upper tropospheric composition: A multi-model study. Atmos. Chem. Phys. 2010, 10, 5719-5738.

30. Roberts, G.; Wooster, M.J.; Lagoudakis, E. Annual and diurnal african biomass burning temporal dynamics. Biogeosciences 2009, 6, 849-866.

31. Giglio, L.; van der Werf, G.R.; Randerson, J.T.; Collatz, G.J.; Kasibhatla, P. Global estimation of burned area using MODIS active fire observations. Atmos. Chem. Phys. 2006, 6, 957-974.

32. Giglio, L.; Randerson, J.T.; van der Werf, G.R.; Kasibhatla, P.S.; Collatz, G.J.; Morton, D.C.; DeFries, R.S. Assessing variability and long-term trends in burned area by merging multiple satellite fire products. Biogeosciences 2010, 7, 1171-1186.

33. Potter, C.S.; Randerson, J.T.; Field, C.B.; Matson, P.A.; Vitousek, P.M.; Mooney, H.A.; Klooster, S.A. Terrestial ecosystem production-A process model based on global satellite and surface data. Global Biogeochem. Cycles 1993, 7, 811-841.

34. Friedl, M.A.; McIver, D.K.; Hodges, J.C.F.; Zhang, X.Y.; Muchoney, D.; Strahler, A.H.; Woodcock, C.E.; Gopal, S.; Schneider, A.; Cooper, A.; et al. Global land cover mapping from MODIS: Algorithms and early results. Remote Sens. Environ. 2002, 83, 287-302.

35. Huffman, G.J.; Adler, R.F.; Morrissey, M.; Bolvin, D.T.; Curtis, S.; Joyce, R.; McGavock, B.; Susskind, J. Global precipitation at one-degree resolution from multi-satellite observations. J. Hydrometeor. 2001, 2, 36-50.

36. Andreae, M.O.; Merlet, P. Emission of trace gases and aerosols from biomass burning. Global Biogeochem. Cycles 2001, 15, 512-525.

37. Christian, T.J.; Kleiss, B.; Yokelson, R.J.; Holzinger, R.; Crutzen, P.J.; Hao, W.M.; Saharjo, B.H.; Ward, D.E. Comprehensive laboratory measurements of biomass-burning emissions: 1. Emissions from Indonesian, African and other fuels. J. Geophys. Res. 2003, 108, 4719:1-4719:13.

38. Hooghiemstra, P.; Krol, M.C.; Meirink, J.F.; Bergamaschi, P.; van der Werf, G.R.; Novelli, P.C.; Aben, I.; Röckmann, T. Optimizing global $\mathrm{CO}$ emission estimates using a four-dimensional variational data assimilation system and surface network obervations. Atmos. Chem. Phys. 2011, $11,4705-4723$.

39. Pétron, G.; Granier, C.; Khattatov, B.; Yudin, V.; Larmarque, J.-F.; Emmons, L.; Gille, J.; Edwards, D.P. Monthly CO surface sources inventory based on the 2000-2001 MOPITT satellite data. Geophys. Res. Lett. 2004, 31, doi:10.1029/2004GL020560.

40. Tansey, K.; Grégoire, J.M.; Defourney, P.; Leigh, R.; Pekel, J.F.; van Bogaert, E.; Bartholomé, E. A new, global, multi-annual (2000-2007) burnt area product at $1 \mathrm{~km}$ resolution. Geophys. Res. Lett. 2008, 35, L01401, doi:10.1029/2007GL031567. 
41. Yarwood, G.; Rao, S.; Yocke, M.; Whitten, G. Updates to the Carbon Bond Chemical Mechanism: CB05; EPA Report Number: RT-0400675; Yocke and Company: California, CA, USA, 2005. Available online: http://www.camx.com/publ/pdfs/CB05_Final_Report_120805.pdf (accessed on 7 February 2012).

42. Chang, D.; Song, Y. Comparison of L3JRC and MODIS global burned area products from 2000 and 2007. J. Geophys. Res. 2009, 114, doi:10.1029/2008JD011361.

43. Wild, O.; Prather, M.J. Global tropospheric ozone modelling: Quantifying errors due to grid resolution. J. Geophys. Res. 2006, 111, D11305.

44. Aghedo, A.M.; Schultz, M.G.; Rast, S. The influence of African air pollution on regional and global tropopsheric ozone. Atmos. Chem. Phys. 2007, 7, 1193-1212.

45. Moxim, W.J.; Levy, H., II.; Kasibhatla, P.S. Simulated global tropospheric PAN: Its transport and impact on $\mathrm{NO}_{\mathrm{x}}$. J. Geophys. Res. 1996, 101, 12621-12638.

46. Chen, Y.; Li, Q.; Randerson, J.T.; Lyons, E.A.; Kahn, R.A.; Nelson, D.L.; Diner, D.J. The sensitivity of $\mathrm{CO}$ and aerosol transport to the temporal and vertical distribution of North American boreal fire emissions. Atmos. Chem. Phys. 2009, 9, 6559-6580.

47 Lapina, K.; Honrath, R.E.; Owen. R.C.; val Martin, M.; Hyer, E.J.; Fialho, P. Late summer changes in burning conditions in the boreal regions and their implications for $\mathrm{NO}_{\mathrm{x}}$ and $\mathrm{CO}$ emissions from boreal fires. J. Geophys. Res. 2008, 113, D11304.

48. Turquety, S.; Logan, J.A.; Jacob, D.J.; Hudman, R.C.; Leung, F.-Y.T.; Heald, C.L.; Yantosca, R.M.; $\mathrm{Wu}$, S.; Emmons, L.K.; Edwards, D.P.; et al. Inventory of boreal fire emissions for North America in 2004: Importance of peat burning and pyroconvective injection. J. Geophys. Res. 2007, 112, D12S03.

49. Leung, F.-Y.T.; Logan, J.A.; Park, R.; Hyer, E.; Kasischke, E.; Streets, D.; Yurganov, L. Impacts of enhanced biomass burning in the boreal forests in 1998 on tropospheric chemistry and the sensitivity of model results to the injection height of emissions. J. Geophys. Res. 2007, 112, D10313.

50. Waters, J.W.; Froidevaux, F.; Harwood, R.S.; Jarnot, R.F.; Pickett, H.M.; Read, W.G.; Siegel, P.H.; Cofield, R.E.; Filipiak, M.J.; et al. The earth observing sysytem microwave limb sounder (EOS MLS) on the aura satellite. IEEE Trans. Geosci. Remote Sens. 2006, 44, 1075-1092.

51. Marenco, A; Thouret, V.; Nédélec, P.; Smit, H.; Helten, M.; Kley, D.; Karcher, F.; Simon, P.; Law, K.; Pyle, J.; et al. Measurement of ozone and water vapour by Airbus in-service aircraft: The MOZAIC airborne program, An overview. J. Geophys. Res. 1998, 103, 25721-25737.

52. Tiedtke, M. A comprehensive mass flux scheme for cumulus parameterization in large-scale models. Mon. Weather Rev. 1989, 117, 1779-1800.

53. Novelli, P.C.; Masarie, K.A.; Lang, P.M. Distributions and recent trends of carbon monoxide in the lower troposphere. J. Geophys. Res. 1998, 103, 19015-19033.

54. Novelli, P.C.; Masarie, K.A.; Lang, P.M.; Hall, B.D.; Myers, R.C.; Elkins, J.W. Reanalysis of tropospheric CO trends: Effects of 1997-1998 wildfires. J. Geophys. Res. 2003, 108, 4464:1-4464:14.

55 Leileveld, J.; Peters, W.; Dentener, F.J.; Krol, M.C. Stability of tropospheric hydroxyl chemistry. J. Geophys. Res. 2002, 107, 4715:1-4715:11. 
56 Fiedler, V.; Arnold, F.; Ludmann, S.; Minikin, A.; Hamburger, T.; Pirjola, L.; Dörnbrack, A.; Schlager, H. African biomass burning plumes over the Atlantic: Aircraft based measurements and implications for $\mathrm{H}_{2} \mathrm{SO}_{4}$ and $\mathrm{HNO}_{3}$ mediated smoke particle activation. Atmos. Chem. Phys. 2011, 11, 3211-3225.

57. Lin, X.; Trainer, M.; Liu, S.C. On the nonlinearity of the tropospheric ozone production. J. Geophys. Res. 1998, 93, 15879-15888.

58. Williams, J.E.; Scheele, M.P.; van Velthoven, P.F.J.; Cammas, J.-P.; Thouret, V.; Galy-Lacaux, C.; Volz-Thomas, A. The influence of biogenic emissions from Africa on tropical tropospheric ozone during 2006: A global modeling study. Atmos. Chem. Phys. 2009, 9, 5729-5749.

59. Jonson, J.E.; Stohl, A.; Fiore, A.M.; Hess, P.; Szopa, S.; Wild, O.; Zeng, G.; Dentener, F.J.; Lupu, A.; Schultz, M.G.; et al. A multi-model analysis of vertical ozone profiles. Atmos. Chem. Phys. 2010, 10, 5759-5783.

60. Lawrence, M.G.; Jöckel, P.; von Kuhlmann, R. What does the global mean OH concentration tell us? Atmos. Chem. Phys. 2001, 1, 37-49.

61. van Leeuwen, T.T.; van der Werf, G.R. Spatial and temporal variability in the ratio of trace gases emitted from biomass burning. Atmos. Chem. Phys. 2011, 11, 3611-3629.

(C) 2012 by the authors; licensee MDPI, Basel, Switzerland. This article is an open access article distributed under the terms and conditions of the Creative Commons Attribution license (http://creativecommons.org/licenses/by/3.0/). 